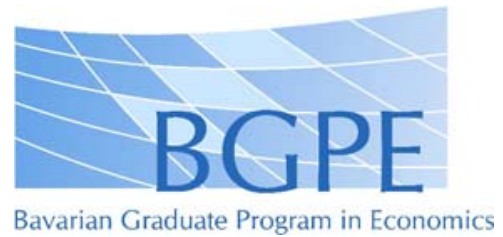

BGPE Discussion Paper

No. 63

\title{
The Transition to Tertiary Education and Parental Background over Time
}

\author{
Regina T. Riphahn \\ Florian Schieferdecker
}

July 2008

ISSN 1863-5733

Editor: Prof. Regina T. Riphahn, Ph.D.

Friedrich-Alexander-University Erlangen-Nuremberg

(C) Regina T. Riphahn, Florian Schieferdecker 
The Transition to Tertiary Education and Parental Background over Time

\author{
Regina T. Riphahn \\ and \\ Florian Schieferdecker
}

28 July 2008

\begin{abstract}
Using SOEP data (1984-2006) we analyze the role of parental background for transitions to tertiary education in Germany and answer three questions: (a) does the relevance of parental background shift from short-term (contemporary income) to long factors (ability, parental education) at higher levels of education? (b) Did the impact of parental background on participation in tertiary education change over time? (c) Are there different patterns by sex and region? We consider panel estimators with and without selectivity corrections and numerous robustness tests. Parental income significantly affects transitions to tertiary education. Its impact seems to have lost magnitude over time. We find no clear differences by sex, and larger parental income effects in West than in East Germany.
\end{abstract}

Key Words: intergenerational transmission, human capital investment, tertiary education, education expansion, college entry

JEL Classification: I2, I23, C25

Correspondence to

Regina T. Riphahn

Economics Department

University of Erlangen-Nuremberg

Lange Gasse 20

90403 Nuremberg

Germany

Phone: $+49-911-5302268$

Fax: $\quad+49-911-5302178$

Email: regina.riphahn@wiso.uni-erlangen.de

We thank Thomas K. Bauer, Knut Wenzig as well as participants of the 2008 meeting of the population economics group of the Verein für Socialpolitik in Bielefeld, seminar participants at the universities of Erlangen-Nuremberg, Linz, Mainz, Milan, Mannheim, and Würzburg for helpful comments. 


\section{Introduction}

Aggregate demand for highly qualified workers as well as the provision of tertiary education increase internationally. At the individual level, tertiary education is a key determinant of wage differentials. This study investigates the role of parental background for individual transitions to tertiary education with a special interest (a) in the relative importance of family ability vs. available financial resources, (b) in changes in the correlation of parental background with college entry over time, and (c) in systematic differences in the relevance of parental background across population groups.

The determinants of entry to tertiary education are of immediate policy relevance for several reasons. First, the large expected demand for a qualified labor force directs political attention to the issue of broadening access to tertiary education (OECD 2007). Second, in societies aiming at equal education opportunities for all children and independent of parental background it is important to learn about the relative impact of various constraints for the transition to higher education. Third, research on college entry is informative with respect to policy instruments supporting college entry, be it tuition remissions or general financial transfers: Cameron and Heckman (2001) suggest that such programs do not work because short-term financial and liquidity constraints are not central in keeping individuals from investing in tertiary education. ${ }^{1}$ Instead, they find the long-run factors that are reflected e.g. in parental educational background and child ability to be key determinants of continued schooling. If our results confirm this conclusion educational policy may have to face up to the ineffectiveness of major policy tools.

This analysis ties in with the literature on intergenerational educational mobility which found for the United Kingdom (Machin and Vignoles 2004, Galindo-Rueda and Vignoles 2005) as well as for Germany (Heineck and Riphahn 2007) that the expansion of higher secondary education mostly benefited the children of well educated and high income

$1 \quad$ This result is disputed by Belley and Lochner (2007) but supported by Mayer (2008). 
parents. Extending these analyses we focus on the transition to tertiary education. The recent literature on college entry in the United States predominantly investigated the development of racial differences over time (e.g. Cameron and Heckman 2001, Black and Sufi 2002, Kane 1994) and the sensitivity of education demand to changes in tuition fees (e.g. Cameron and Taber 2004, Dynaski 2003, Hilmer 1998). Relevant European studies on college entry are Lauer (2003) who compares the selection into higher education for Germany and France, Rice (1987) and Leslie and Drinkwater (1999) who investigate the transition to tertiary education in the United Kingdom, and Checci et al. (2008) who study the Italian case.

Among numerous sociological contributions on the role of parental background for child tertiary education in Germany, Blossfeld (1993) described educational outcomes for the birth cohorts 1916-1960. With respect to the transition to tertiary education he finds positive effects of paternal education and occupational prestige which are, however, weaker than for secondary education outcomes. There is no clear trend across birth cohorts. The author makes no attempt to control for sample selection at higher educational outcomes. ${ }^{2}$ Lauer (2002) investigates the determinants of enrolment in tertiary education in Germany testing a broader set of hypotheses. She finds a significant effect of the student financial assistance scheme. This is not confirmed by Baumgartner and Steiner $(2005,2006)$ who take advantage of two reforms of the student financial assistance scheme to identify its effects. However, Steiner and Wrohlich (2008) do find significant effects of student assistance and of parental income on college enrolment in Germany. Most of these papers consider only graduates of the German advanced secondary schools (Gymnasium) but omit sample selection controls.

Our study contributes to the existing literature on the intergenerational transmission of education in several ways: it provides evidence on the relative impact of short-run and longrun determinants of tertiary education in a large European country, it describes the

\footnotetext{
2 This methodological shortcoming also characterizes more recent sociological analyses of education transmission in Germany, e.g. Mayer et al. (2007), Maaz (2006).
} 
developments over more than two decades separately for males and females, and it contrasts the developments in East and West Germany using the rich and representative data of the German Socioeconomic Panel (1984-2006). We allow for endogenous selection into subsequent educational stages, control for individual ability, and test whether the potential endogeneity of parental income affects our findings.

Our key results are that both long-run and short-run factors appear to affect the transition to tertiary education in Germany as long as selection into high secondary schooling is not accounted for. When controlling for the selectivity inherent in attaining university access only parental income remains a significant determinant of college entry. There is a slight indication that the impact of parental income on transitions to tertiary education declined over time. We find no clear differences in the patterns behind college entry by sex, and larger parental income effects in West than in East Germany.

\section{Institutional Background}

The German secondary school system is organized in three tracks. Typically at the age of 10 and after four grades in elementary school, pupils are sorted in three secondary school tracks: a basic school which prepares for blue collar vocational apprenticeships, a middle school with higher requirements preparing for white collar vocational training, and an advanced school (Gymnasium) which prepares for academic studies. ${ }^{3}$ The final degree of the Gymnasium, the Abitur, is the entrance requirement for tertiary education. Besides classic universities the German tertiary education system entails polytechnical universities (Fachhochschulen).

While traditionally less than 20 percent of a birth cohort completed advanced school and attained academic entrance requirements, recent decades witnessed a massive expansion

\footnotetext{
3 In addition, there are comprehensive schools where pupils can obtain either level of education. However, only a share of about four percent of every cohort attends these.
} 
of the educational system: Figure 1 depicts the development of the population shares attaining Abitur by birth cohort, Table 1 describes more recent cohort shares with Abitur separately for males and females based on administrative data. The development over time (see columns 1 and 2) suggests that the education expansion benefited particularly females. While one might suspect that part of this development is due to unification and different gender roles in former East Germany, we find massive educational improvements also for females in West Germany alone (see column 6).

We focus on pupils who graduate from Gymnasium. Our data allow us to follow them for the first five years after the Abitur and to observe whether they take up tertiary education. Figure 2 provides aggregate data on the distribution of delays in college entry by gender over time. The figures suggest that only small cohort shares take up academic education later than three years after obtaining the Abitur. As we observe individuals up until five years after Abitur our data should cover the vast majority of individuals ever taking up tertiary education after meeting the entrance requirements.

Figure 2 suggests noticeable gender differences in the timing of university entry which are most likely due to the military service requirements for males. ${ }^{4}$ Whereas around 40 percent of all females take up tertiary education in the very year they leave Gymnasium, this immediate transition rate recently amounts to less than 20 percent for men. In their majority they enter academics one year later. The share of Gymnasium graduates that never commences tertiary education is larger among females than among males.

In view of the rising cohort shares with Gymnasium degrees (see Figure 1, Table 1), it is of interest to examine the development of cohort shares taking up tertiary education over time. Figure 3 depicts the annual number of entering students since 1975, which has more

\footnotetext{
$4 \quad$ The requirements for male military or substitute civil service have been shortened in recent years. The duration of military service was shortened from 15 months (1984-1990), to 12 months (1990-1996), 10 months (1996-2002), and nine months since 2002. Alternative civilian service obligations were as high as 20 months (1984-1990), then 15 months (1990-1996), reaching 10 months between 2002 and 2004, and nine months since.
} 
than doubled since. Table 2 presents entry rates by gender across all institutions of tertiary education. Clearly, both the cohort share of males and females entering tertiary education increased strongly over the last decades and females caught up with males. ${ }^{5}$ Aggregate data suggest that also the cohort shares with completed tertiary degrees have been going up (for recent evidence by sex see Table 3).

Tertiary education has been subject to institutional reforms over time (for a description see e.g. Mayer et al. 2007). As documented e.g. by Heineck and Riphahn (2007) the entire education system in Germany experienced an expansion over the last decades. Table 4 summarizes key budgetary developments regarding the tertiary education system: the total number of students and nominal expenditures increased, while the expenditures as share of GDP, teacher-student ratios and expenditures per student declined.

In addition, a number of reforms affected the investment decision of the individual high school graduate. For the time of our data there were basically no tuition fees in German public tertiary education except for administrative fees of around 100 Euro per semester. For students in financial need, i.e. when parental income is below a fixed cutoff level, a support system has been available for decades to cover students' costs of living (it pays a maximum of about 370 Euro per month as of 2004). This support system has undergone a number of reforms: until 1974 it was a full grant, later an increasing share was provided as a loan. Since 1983 the support was granted as a full loan to be repaid with interest. In 1990 a reform reinstated that half of the support was provided as an unconditional transfer and half as an interest-free loan. In 2001 the benefit amount was increased and the fixed cutoff level of parental income rose by 20 percent.

\footnotetext{
$5 \quad$ It is not useful to compare the rates in Table 2 to those in Table 1 or Figure 1 as Table 2 combines all individuals entering tertiary education in a given calendar year, independent of their age, while Table 1 and Figure 1 condition on the year of leaving school. As cohort sizes vary substantially over time the difference in conditioning affects the cohort shares.
} 


\section{Literature and Hypotheses}

Prior literature has paid attention to both, the intergenerational transmission of income and of educational attainment between parent and child. Among the central mechanisms explaining this transmission are the genetic inheritability of ability, parenting quality, parental income, and other environmental factors. Parental income and wealth find particular attention in the debate about equal access to education. Since parental income is potentially correlated with unobserved determinants of child educational outcomes numerous studies focus on identifying its true causal effect. Some use social experiments that affect family income (e.g. Clark-Kauffman et al. 2003), others apply various instrumental variables (e.g. Blanden and Gregg 2004), and others again control for fixed family- or individual-specific unobservables, e.g. by comparing the outcomes for siblings and twins (see Tamm 2007) or for adopted and non-adopted children (Plug and Vijverberg 2003).

Besides the literature which studies the correlation of income and child educational attainment at a given point in time, other analyses investigate trends in intergenerational transmission. In an important contribution Cameron and Heckman (1998) evaluate the development for American males born between 1907 and 1964. They distinguish the effects of family income at the time when the schooling decisions were to be taken (short-run effects) from the effects of parent and child ability endowments (long-run effects). The authors stress the phenomenon of dynamic selection bias: the selective educational progress of those with the best unobservable characteristics can lead to biased estimates of the impact of family background. After the first educational selection stage individual unobservables are no longer statistically independent of observable background characteristics. In their 1998 study Cameron and Heckman find that short-run income effects hardly matter for the transition to tertiary education. This is confirmed by Cameron and Heckman (2001), but disputed by Belley and Lochner (2007) who consider data on younger birth cohorts in the 
United States. Similar results are obtained by Blanden and Machin (2004) who look at British data. However, the two latter studies do not control for dynamic selection bias.

We follow the Cameron and Heckman-set up and compare the relevance of short- and long-run effects over subsequent birth cohorts in order to identify the impact of short-run parental income after controlling for the long-run ability characteristics of the family. It is this conditional short-term income effect which is of foremost political interest as it is the only determinant of educational outcomes which transfer programs may be able to affect directly. The identification strategy typically applied to measure short-run income effects consists of controlling both for general family ability (measured e.g. via parental education) as well as for unobservable ability of the individual using e.g. intelligence test scores. Only if family income affects educational choices after conditioning on these factors can we expect policies to be successful which attempt to affect the enrolment of the smart poor by providing relief to short-term liquidity restrictions.

Some analyses of the determinants of educational outcomes at the tertiary level discuss cost-benefit considerations (e.g. Black and Sufi (2002), Kane (1994) and for a recent survey Kane (2006)) and use empirical specifications which approximate the cost (e.g. the level of tuition) and benefits (expected returns to tertiary education) of tertiary education. In the German case it is difficult to come up with indicators of either measure. First, for the time of our data there were no university fees. Therefore the only relevant cost would be the opportunity cost of studying which hardly differs across high school graduates. Even more uncertainty governs the benefits of education. Most of the heterogeneity in expected benefits derives from the field of study which we do not observe and which is endogenous. Therefore we model the transition to tertiary education without explicitly controlling for cost and benefit indicators. We specify the transition to tertiary education as follows:

$$
\begin{aligned}
\mathrm{P}(\text { tert. education })=\mathrm{f}\left(\alpha+\beta_{1} \text { parental education }+\beta_{2} \text { child ability }+\gamma\right. \text { parental income } \\
\\
\left.+\delta_{1} \text { sex }+\delta_{2} \text { federal state } \mathrm{FE}+\delta_{3} \text { calendar year FE }\right),
\end{aligned}
$$


where $\alpha, \beta, \gamma$, and $\delta$ indicate parameter vectors to be estimated. A key disadvantage of our data is that it does not provide a general indicator of individual ability, such as an IQ test score or average grade at school for all observations. We consider the indicator individual age at Abitur as a proxy for individual ability and expect that those individuals who finish secondary school faster than their peers are on average of higher ability. Taking a year longer e.g. after repeating a grade or after entering school late, might indicate difficulties in reaching age-specific learning objectives at some point in the individual's past. As the SOEP provides grade information (for mathematics, German, and a foreign language) in its more recent surveys we apply these indicators in robustness tests. ${ }^{6}$ Our specification controls for a measure of parental income, youth sex as well as region and calendar year fixed effects. The regional controls are important as German educational policy is determined at the state level.

\section{Data Description}

We use annual data of the German Socio-Economic Panel (SOEP, 1984-2006). The SOEP is a representative household panel survey which gathers information on a variety of topics, some annually, others only in certain survey years (SOEP Group 2001). The SOEP is the only German dataset which provides information on parental background and allows one to follow high school graduates and their human capital investments over time.

As we are interested in the transition of Gymnasium graduates to tertiary education, our sample consists of individuals who are observed to graduate from Gymnasium. ${ }^{7}$ The most common age at which pupils attain this degree is 19 or 20 . We restrict our sample to those individuals who were not older than 25 when they graduated and - to allow for reliable

\footnotetext{
$6 \quad$ We used the small samples with available grade information to compare individual grades by age at Abitur. In two out of the three subjects (German and foreign language) those individuals who completed the Abitur early, i.e. at age 17 or 18, indeed had better grades than those who graduated at older age.

$7 \quad$ Individuals who did not indicate to attend school in the year before they first claimed a high school degree are not considered in the group of new high school graduates.
} 
measures of parental background and income when the youth was age 19 - we consider only those individuals who were SOEP respondents already prior to age 20.

The SOEP asks every person annually about the highest degree attained. As we are interested in the timing of secondary school graduation and college entry, we have to account for the timing of SOEP interviews, which can take place in any month during the year (most are administered in the first quarter). Since graduation from secondary school typically takes place in June or July, we assume that individuals who newly indicated a high school degree in an interview prior to June graduated in the year before, e.g. if an individual did not have an advanced school degree in the interview of April 2003 and indicated an advanced school degree in January 2004, we assume that the degree was attained in June or July of 2003. If, however, the 2004 interview took place in July we assume that the degree was attained in 2004. Overall, the data allow a precise and unambiguous timing of the Abitur event in 96.5 percent of all cases.

In total and over the course of 23 survey years we observe 1170 individuals graduating from Gymnasium. ${ }^{8}$ Figure 4 describes the distribution of the observed events over time. It confirms the rising cohort share of female graduates which we also encountered in the aggregate data (cf. Table 1). In our sample 555 male and 615 female Gymnasium graduates are at risk of entering tertiary education, where we consider transitions to universities and polytechnicals (Fachhochschulen) jointly because the data do not allow us to separate the two institutions. Our dependent variable indicates whether an individual commenced tertiary education in a given year. The distribution of our SOEP secondary school graduates by age is presented in Figure 5, which shows that at least 75 percent of the graduates are either age 19 or $20 .^{9}$

\footnotetext{
$8 \quad$ Individuals attaining a "Fachabitur" degree are not part of our sample because they are not eligible for university education.

$9 \quad$ In the regression we adjust the age at Abitur variable for individuals who graduated in states with shorter Gymnasium schooling requirements: in Thuringia and Saxony-Anhalt the Abitur can be attained after 12 instead of 13 years of schooling, which were required everywhere else during the time of our observations.
} 
In order to correctly time the entry to tertiary education further adjustments are required. Academic degree programs typically start in the fall term, i.e. in October. Therefore we coded individuals who were interviewed prior to October of year $t$ and indicated for the first time to be students to have started their academic education in year $t-1$. Individuals who were interviewed in November of year $t$ and indicated for the first time to be students were considered to be students since October of year $t$. We observe a total of 754 entries to tertiary education, 377 men and 377 women. Our aggregate transition rate to tertiary education - by year five after high school graduation - thus reaches 64 percent, i.e. 68 and 61 percent among men and women, respectively. This is below aggregate figures: the Federal Statistical Office (StBA, 2006, p.144) finds that between 83 and 73 percent of those graduating from Advanced School between 1985 and 2000 at some point took up tertiary education. ${ }^{10}$ Figure 6 depicts the share of Gymnasium graduates by year of graduation, who, over the course of our observation period were observed to start a tertiary education. Despite the small number of observations we find an about constant cohort share between 60 and 70 percent with only the most recent cohorts dropping off, because they had not completed their education.

We follow individuals for up to 5 years after their high school diploma to code college entry. As in the aggregate data females are much more likely to take up their studies immediately than males. Table 5 presents the unweighted distribution of the time until takeup of tertiary education in our sample for those graduates who were observed for the entire first five years after high school graduation. A larger share of males than females is observed to enter university or polytechnical schools. Two years after secondary school graduation more than half of the graduation class has entered tertiary education for both sexes.

$10 \quad$ A panel survey of Advanced School graduates yielded that between 18 and 29 percent of males and 29 and 39 percent of females did not plan to take up tertiary education half a year after leaving Advanced School (Heine et al. 2006). The remaining difference in transition rates with our data is partly due to transitions to tertiary education outside of our observation window (i.e. after year five after the Abitur) and partly to panel attrition of young individuals in the German Socioeconomic Panel. 
Our first research question focuses on the long-run and short-run determinants of transitions to tertiary education. Following Cameron and Heckman (2001), we consider parental income at age 19 as a short-run factor that might influence individuals' decision to take up an academic education. In our baseline model we consider household net equivalence income, coded as the percentile rank in the annual distribution of household equivalence incomes. We use the rank position to generate income measures that are comparable over time. Since the amount of parental income that is disposable for investments in child education varies with household size, we use equivalent income defined as net income over the square root of household members. ${ }^{11}$

Long-run factors are those which influence individuals since the early ages of childhood and individuals' unobserved ability. We consider parental educational background as indicative of such long-run characteristics, as more able parents tend to be better educated and to have more able children on average. ${ }^{12}$ Parental educational background is coded in four categories: missing information or other schooling, no degree or only basic school, middle school, and Gymnasium with or without tertiary education. The indicator reflects the higher of paternal and maternal education. While parental education can be considered as an indirect indicator of (inheritable) child ability, we consider the age at which the child graduated from Gymnasium as a direct indicator.

As a first description of the relevance of parental income, Table 6 depicts transition rates to tertiary education conditional on Abitur by parental education. The first row shows that the propensity to enter advanced education, conditional on attaining the Abitur increases almost linearly with parental education. A comparison of the entries in columns (2) and (4) implies a disadvantage in college entry rates of about 14 percentage points for children of

\footnotetext{
11 Ideally, one might want to control for the number of siblings supported by parents, however this information is not available for all observations in our sample. In a robustness test (discussed below), we determine whether the equivalence correction affects our results.

12 The psychological literature clearly indicates the inheritability of ability, see e.g. Plomin et al. (2001).
} 
parents with at most basic school education (60 percent) compared to children of parents with academic degrees (74 percent). The next row indicates the respective probabilities after holding household income constant at the observed level of parents with high education. Income appears to eliminate three percentage points out of the 14 point gap between columns (2) and (4) and three points of the 13 point gap between columns (3) and (4). Thus, adjusting for income explains only a small share of the observed differences in probabilities.

Figures $7 \mathrm{a}$ and $7 \mathrm{~b}$ depict the probability of attaining the Abitur degree as well as the probability of starting tertiary education after Abitur as a function of parental education by income group. The probability of attaining the Abitur varies much more strongly with parental education than with parental income. The evidence for the transition to tertiary education is not as clear. Here, we find high transition rates among those with missing income information. It is surprising to see higher transition rates for children of parents with no or only low educational degrees than for children of parents with middle degrees in three of the four income quartiles. However, the number of observations in the missing $(\mathrm{N}=27)$ and low education category is small $(\mathrm{N}=207)$. Conditioning on parental education we see a positive income effect in all groups. A comparison across the two figures suggests that parental ability loses significance when focusing on tertiary instead of secondary education.

\section{Empirical Approach}

While most authors (e.g. Blossfeld 1993 or Belley and Lochner 2007) estimate the correlates of educational outcomes in a cross-sectional regression, Cameron and Heckman (1998, 2001) stress that this may lead to biased results. If both, observable and unobservable characteristics determine educational success at any given stage, and thus affect the eligibility for a transition to the next stage, then over subsequent steps of the education process the unobservables will be negatively correlated with the observable outcomes: if on average children of parents with high socioeconomic status move on, then the children of parents with 
low socioeconomic status who are able to keep up must have a particularly positive set of unobservable characteristics. In order to determine the unbiased effect of socioeconomic variables on the educational attainment of interest it is necessary to control for this selection.

We provide estimates with and without a correction for this selection process. To control for selection, we apply a full information maximum likelihood bivariate probit estimator. As a first stage we model whether or not an individual attains the Abitur degree. The error term is allowed to be correlated with the error term of the second stage probit regression, which models the transition to tertiary education conditional on attaining the Abitur. Three issues are to be discussed for this standard framework: a first complication derives from the panel nature of our data. In our main equation of interest we model the discrete time hazard of a transition to tertiary education, conditional on attaining the Abitur within the last 5 years and conditional on not having entered tertiary education before. ${ }^{13}$ We use the following setup:

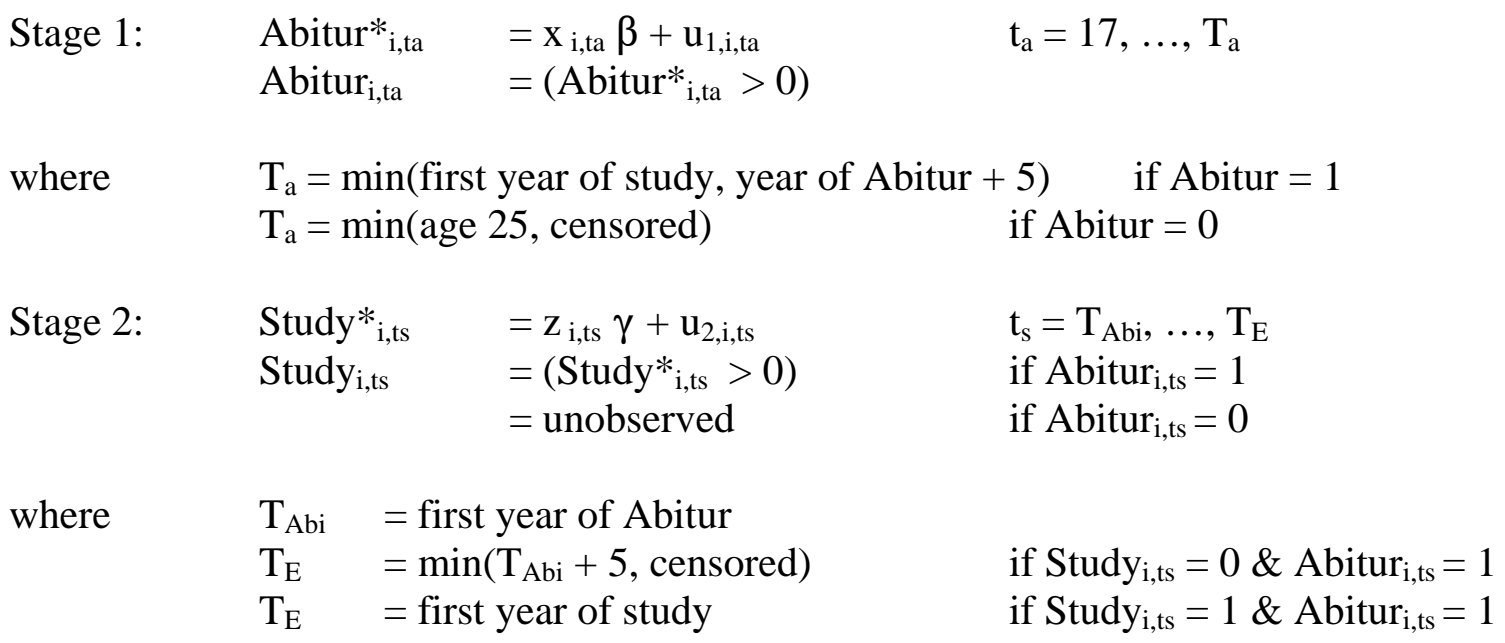

where $\mathrm{u}_{1} \sim \mathrm{N}(0,1), \mathrm{u}_{2} \sim \mathrm{N}(0,1)$, and $\operatorname{corr}\left(\mathrm{u}_{1}, \mathrm{u}_{2}\right)=\rho$. Abitur ${ }_{\mathrm{i}, \text { ta }}$ and Study ${ }_{\mathrm{i}, \text { ts }}$ are latent, unobserved variables which reflect the propensity to graduate from Gymnasium and to enter tertiary education, respectively. $\mathrm{x}$ and $\mathrm{z}$ represent the vectors of explanatory variables

13 This longitudinal modeling strategy goes beyond the classic bivariate probit application as it requires panel data also for the first stage selection equation. 
considered in the two probit models. $\beta$ and $\gamma$ are vectors of coefficients, and $\mathrm{u}_{1}$ and $\mathrm{u}_{2}$ are residuals of the latent variable models.

As a second issue we need to account for observing every individual repeatedly until either entering tertiary education or being censored. We use clustered standard errors at the individual level in order to increase the efficiency of our estimation.

The third issue concerns identification and the specification of our models. Though the model is identified by functional form we apply several exclusion restrictions to strengthen identification. Based on aggregate school data we coded the share of a given state's pupils attending Gymnasium prior to an individual's entry at Gymnasium. This timevarying indicator is expected to reflect the state-level education supply conditions when a pupil was assigned to a secondary school track at about age ten. It should affect the individual propensity to attain the Abitur degree without affecting the individual probability of taking up tertiary education. A second indicator describes the rigor with which states select pupils allowed to enter Gymnasium. Some states use objective grade restrictions while others permit parental school choice independent of prior child educational attainments. This indicator of parental influence may affect the probability to attain the Abitur degree but should not affect entry to tertiary education. In addition, we consider the age of father and mother at birth of the child and indicators of whether these measures are missing in the data. High parental age is known to increase the probability of attaining the Abitur but should not affect subsequent transitions to tertiary education (cf. Belley and Lochner 2007).

In sum, the Abitur outcome is regressed on indicators of parental education and income, vectors of federal state and calendar year fixed effects, individual age and sex, and as instruments - the time-varying state-specific share of pupils attending Gymnasium, the state specific rigor of Gymnasium admission, and the age of both parents. The regression for college entry controls for parental education and income, individual sex, immigrant status, years since graduating from Gymnasium and age at attaining the Abitur, as well as vectors of 
state and year of Abitur fixed effects. In modeling annual transition probabilities we additionally control for the baseline hazard of transitions to tertiary education using a vector of indicators for "years since Abitur". Descriptive statistics of the explanatory variables for the two regression equations are presented in Table 7.

\section{Results}

In order to evaluate the relative impact of long-term and short-term determinants of college entry we estimate their marginal effects in three different empirical specifications. Cameron and Heckman (1998) find that the effect of family income greatly weakens after controls for long-term factors are added to the model. In Table 8 we present the marginal effects obtained in probit estimations of the outcome "transition to tertiary education" for three specifications. Specification (a) considers controls for parental education, specification (b) additionally controls for household equivalent income, and specification (c) omits the controls for parental education and considers the household equivalent income, only. Panel A presents the marginal effects based on estimations for the sample holding the Abitur degree, Panel B shows the marginal effects after correcting for the potential sample selection bias when conditioning on those who hold the Abitur degree.

In Panel A of Table 8 parental education yields the expected effects: the probability of a transition to tertiary education is highest for those with highly educated parents with an advantage of close to ten percentage points over children of parents with only basic school education. The parental education effects are jointly highly statistically significant. Also, the controls for age at Abitur are jointly significant. However, they indicate the highest probability of a transition to tertiary education for those who attained the Abitur at the (regular) age of 19 or 20 years. If early Abitur is correlated with high ability this does not seem to translate to a higher probability of a transition to university. The parental income indicators considered in specifications (b) and (c) are also jointly highly significant: parental 
income is positively correlated with the probability of a transition to tertiary education. The baseline hazard indicators of years since Abitur are highly significant and indicate the highest transition probability in year 1 after the Abitur (marginal effects not presented to save space).

It is of particular interest to compare the effects of parental education and parental income. In Panel A both covariate groups show significant marginal effects of comparable size. Compared to either specification (a) or (c), the marginal effects of education and income decline slightly when both indicator groups are considered jointly in specification (b), but they remain statistically significant.

The results differ somewhat in Panel B, where the effect of non-random selection into the Abitur is controlled for. Our instruments in the first stage regression and the error term correlation between $\mathrm{u}_{1}$ and $\mathrm{u}_{2}$ are significantly different from zero (see bottom rows of Tables 8B and A1). ${ }^{14}$ The negative correlation of the unobservables suggests that individuals with positive residuals in the Abitur-equation tend to have negative residuals in the study-equation (and vice versa), i.e. those who attain the Abitur against the odds of their characteristics have a lower probability to move on to tertiary education than those who are expected to attain the Abitur. In other words, parents may be able to push their children despite their poor odds to high school graduation, but their influence does not extend to the tertiary level.

The main difference when comparing Panels A and B is that the marginal effects of parental education lose statistical and economic significance. In Panel B they are small and imprecisely measured whereas the effects of parental income hardly change compared to those in Panel A. The intuition of the disappearing parental education effect is difficult to grasp given its significance both, in the unconditional estimates and in the first stage

\footnotetext{
14 In addition to testing the joint significance of our instruments in the Abitur-equation we performed an overidentification test as described in Bratti (2007): since the estimator is identified by functional form we omitted the instruments from the first-stage (Abitur) equation and added them to the second-stage equation. Here they were neither individually nor jointly statistically significant (p-value of joint test: 0.5929).
} 
regression (for results of the first stage regression see Table A1 in the Appendix ${ }^{15}$ ). However, the central result is that - in contrast to some results obtained for the United States - even after sample selection correction parental income is significant for the transition to tertiary education. Parental income in the top quartile increases the transition probability to tertiary education by almost ten percentage points relative to parental income in the bottom quartile.

Our second research question addresses the relevance of parental background over time. We split the observation period in West Germany in three subperiods and re-estimated the probit and selection models separately for each of the three periods using the same specification as in Table 8. The number of observations at the second stage equation is now strongly reduced. The results are depicted in Table 9: now, the parental education effects no longer indicate the positive and significant effects on transitions to tertiary education. The marginal effect is highest for those attaining the Abitur in the middle period and it reverses in sign in the last period, both in Panel A and in Panel B. The marginal effects of parental income are jointly statistically significant only for the first group of graduates. In later years the marginal effects of parental income decline in magnitude or turn negative. These results suggest a slight reduction in the relevance of both parental income and education over time.

As a robustness check we re-estimated specification (b) of Table 8 for the full model adding interactions of a linear time trend with parental background effects. While interaction terms in nonlinear models are to be handled with care (Ai and Norton 2003) the resulting coefficients confirm our conclusions based on the more flexible specifications used in Table 9: all parental education interactions with the time trend are statistically insignificant. They yield small positive interaction terms for parental education. The interactions with parental income are small and positive without selection correction and negative when selection

\footnotetext{
15 Interestingly, the marginal effect of parental education is substantially stronger and that of parental income is much smaller for the first stage outcome. This confirms the broad sociological evidence on changing parental background effects at increasingly higher educational stages.
} 
corrections are considered. Thus we find no clear or substantial development and possibly a slight decline in the relevance of parental income over time.

Finally, we investigate the heterogeneity of parental background effects across population groups. Table 10 presents the marginal effects of the two probit estimations separately for males and females in West German states. ${ }^{16}$ In both cases we obtain (statistically insignificant) positive effects of parental education for males. As in the full sample (cf. Table 8) the positive effect of parental education for females disappears once selection corrections are considered. The parental income effect yields the expected sign for both groups in both panels. It is more precisely estimated and slightly larger for males. The results confirm that the effects of parental income dominate the education effects.

Table 11 compares the impact of parental background for East and West Germans. As before, we find positive marginal effects of parental education in Panel A, only. These effects are of comparable size for the two subsamples. The effect of parental income for the West German sample is generally positive but not precisely measured. The patterns are less clear in the case of the East German sample where children of parents with missing income information have by far the largest probability to start tertiary education. The income information is missing for about 8 percent of the East German sample, i.e. 24 of 311 East German Abitur holders. When we dropped these observations, the magnitude of the other income effects hardly changed and the negative correlation of high income and the transition to tertiary education remained. This suggests that the positive marginal effect of parental income is limited to the West German part of our sample.

We applied various robustness tests to evaluate the reliability of our results. While our main estimation approach uses the panel character of our data to describe the transition to

16 The number of observations in East Germany (824) appears to be too small to split this sample. 
tertiary education, the same outcome can also be reflected in a cross-sectional setting: here a first stage regression models whether an individual attains the Abitur between ages 17 and 25, and a second stage models whether a transition to tertiary education is observed within the first five years after Abitur. While controls for the baseline hazard and for calendar year fixed effects are not possible in the cross-sectional framework, we obtained the same pattern of highly significant effects of parental income for the transition to tertiary education, both in models with and without selection controls (results not presented to save space).

As another robustness test of the panel estimation results, we applied an alternative income measure and used the rank in the household net income distribution without equivalence scale adjustments. Our results remained unchanged. Next, we considered the possibility that income was closely affected by parental education. To test whether and how this influences our results we replaced our income measure by an indicator that was orthogonal to parental education: in a first step we regressed income on maternal and paternal education indicators. Then we calculated the residual from this auxiliary regression and used it as an income indicator. This correction did not affect our results. ${ }^{17}$

As a fourth robustness test, we applied a linear probability model for the second stage of our sample selection model. The nature of the results for long and short-term effects, over time and across subsamples was robust to this alternative estimation approach.

Finally, we replaced our indicator of student ability by a more potent measure. In the survey years after 2000 the German Socioeconomic Panel asked every pupil about grades in mathematics, German and a foreign language. We expect that grades are closely correlated to scholastic abilities. We reestimated the three specifications in Table 8 for the subsample interviewed after 2000 now adding controls for grades. The results for this subsample with and without grade controls are presented in Table A3 in the Appendix. We assume that it is

\footnotetext{
17 After taking these ability related determinants of income out of the income indicator the estimated marginal effect may be interpreted as the 'nurture' effect of income, as opposed to genetic or 'nature' effects.
} 
the much reduced sample size which causes the overall loss in statistical significance of the estimation results. When comparing the marginal effects in the specifications with and without controls for grades we find hardly any difference at all. While the vector of grade indicators is jointly statistically significant controlling for grades thus does not change the marginal effects of parental education or income. This suggests that our results presented on the full sample above are not biased due to insufficient controls for abilities.

\section{Conclusions}

This study extends the economic analysis of intergenerational education mobility in Germany to the transition to tertiary education. We apply rich panel data to carefully describe graduation from secondary school and college entry over a period of more than 20 years. In this period the German educational system continued to expand and it is important to ask who benefited from this expansion. The literature on educational mobility with respect to German secondary school attainment suggests that intergenerational educational mobility did not increase in the wake of education expansion.

However, Cameron and Heckman $(1998,2001)$ point out that the mechanisms determining educational attainment are not constant across subsequent educational outcomes. Therefore different results are possible for educational mobility at the secondary and tertiary education level. While these authors find for the U.S. birth cohorts through 1965 that at advanced educational levels the impact of parental income declines and only that of parental ability remains important, their finding is not confirmed when Belley and Lochner (2007) extend the analysis to consider the birth cohorts through 1985. Belley and Lochner (2007) conclude that the impact of parental income on college attendance increased "dramatically."

In our investigation of the German case we find that the relevance of parental background varies depending on the level of education considered. Parental income is positively correlated with the probability of a transition to tertiary education. This result is 
robust to controls for the non-random selection into the group attaining the Abitur degree in secondary school and to controlling for child ability and parent educational background. This suggests that predominantly the children of rich parents benefit from wider access to tertiary education. Our analysis of developments over time is limited by small sample sizes, but indicates that the relevance of parental income declined over the considered period.

The differences in the parental background effects across population groups are estimated here in very flexible settings which allow all determinants of the transition to tertiary education to vary across population groups. In this framework we do not find clear and unambiguous patterns except that parental income plays a somewhat larger role for West German males than for females and that parental income may matter less for transitions to tertiary education among East than West Germans.

Overall, we cannot reject the hypothesis that parental income affects young individuals' decision to move on to tertiary education. In consequence, public programs balancing differences in parental financial background may affect college entry decisions. Therefore the recent introduction of tuition fees in several German states should affect the composition of the student population, posing an intriguing question for future research. 


\section{Bibliography}

Ai, Chunrong and Edward C. Norton, 2003, Interaction terms in logit and probit models, Economics Letters 80, 123-129.

Baumgartner, Hans J. and Viktor Steiner, 2005, Student Aid, Repayment Obligations and Enrolment in Higher Education in Germany - Evidence from a "Natural Experiment", Schmollers Jahrbuch 125, 29-38.

Baumgartner, Hans J. and Viktor Steiner, 2006, Does More Generous student Aid Increase Enrolment Rates into Higher Education? Evaluating the German Student Aid Reform of 2001, IZA Discusson Paper Nr. 2034, Bonn, Germany.

Belley, Philippe and Lance Lochner, 2007, The Changing Role of Family Income and Ability in Determining Educational Achievement, Journal of Human Capital 1(1), 37-90.

Black, Sandra E. and Amir Sufi, 2002, Who goes to college? Differential enrollment by race and family background, NBER Discussion Paper No. 9310, Cambridge, USA.

Blanden, Jo and Stephen Machin, 2004, Educational Inequality and the Expansion of UK Higher Education, Scottish Journal of Political Economy 51(2), 230-249.

Blanden, Jo and Paul Gregg, 2004, Family Income and Educational Attainment: A Review of Approaches and Evidence for Britain, Oxford Review of Economic Policy 20(2), 245-263.

Blossfeld, Hans-Peter, 1993, Changes in Educational Opportunities in the Federal Republic of Germany. A Longitudinal Study of Cohorts Born Between 1916 and 1965, in: Shavit, Yossi and Hans-Peter Blossfeld (eds.), 1993, Persistent Inequality. Changing Educational Attainment in Thirteen Countries, Westview Press: Boulder et al., 51-74.

Bratti, Massimiliano, 2007, Parents' income and children's school drop-out at 16 in England and Wales: evidence from the 1970 British Cohort Study, Review of Economics of the Household 5(1), 15-40.

Cameron, Stephen V. and James J. Heckman, 1998, Life Cycle Schooling and Dynamic Selection Bias: Models and Evidence for Five Cohorts of American Males, Journal of Political Economy 106(2), 262-333.

Cameron, Stephen V. and James J. Heckman, 2001, The Dynamics of Educational Attainment for Black, Hispanic, and White Males, Journal of Political Economy 109(3), 455-500.

Cameron, Stephen V. and Christopher Taber, 2004, Estimation of Educational Borrowing Constrainst Using Returns to Schooling, Journal of Political Economy 112(1- pt.1), 132-182.

Checchi, Daniele, Carlo V. Fiorio, and Marco Leonardi, 2008, Intergenerational Persistence in Educational Attainment in Italy, mimeo, Univ. of Milan.

Clark-Kauffman, Elizabeth, Greg J. Duncan, and Pamela Morris, 2003, How Welfare Policies Affect Child and Adolescent Achievement, American Economic Review 93(2), 299-303.

Dynarski, Susan M., 2003, Does Aid Matter? Measuring the Effect of Student Aid on College Attendance and Cempletion, American Economic Review 93(1), 279-288.

Galindo-Rueda, Fernando and Anna Vignoles, 2005, The Declining Relative Importance of Ability in Predicting Educational Attainment, Journal of Human Resources 40(2), 335-353.

Heine, Christoph, Heike Spangenberg, Dieter Sommer, 2006, Studienberechtigte 2004 - Übergang in Studium, Ausbildung, Beruf. Ergebnisse der Befragung der Studienberechtigten 2004 ein halbes Jahr nach Schulabgang im Länder- und Zeitvergleich, HIS Hannover.

Heineck, Guido and Regina T. Riphahn, 2007, Intergenerational Transmission of Educational Attainment in Germany: The Last Five Decades, DIW Discussion Paper No. 738, Berlin, Germany. 
Hilmer, Michael J, 1998, Post-secondary fees and the decision to attend a university or a community college, Journal of Public Economics 67, 329-348.

Kane, Thomas J., 1994, College Entry by Blacks since 1970: The Role of College Costs, Family Background, and the Returns to Education, Journal of Political Economy 102(5), 878-911.

Kane, Thomas J., 2006, Public intervention in post-secondary education, in: Hanushek, Eric A. and Finis Welch, Handbook of the Economics of Education, Vol.2, 1369-1401.

KMK (Sekretariat der Ständigen Konferenz der Kultusminister der Länder), 2005, Prognose der Studienanfänger, Studierenden und Hochschulabsolventen bis 2020, Statistische Veröffentlichungen der Kultusministerkonferenz - Dokumentation Nr. 176, Bonn, Germany.

Köhler, Helmut, 1990, Neue Entwicklungen des relativen Schul- und Hochschulbesuchs. Eine Analyse der Daten für 1975-1987, Materialien der Bildungsforschung Nr. 37, Max Planck Institut für Bildungsforschung, Berlin, Germany.

Lauer, Charlotte, 2002, Participation in higher education. The role of cost and return expectations, International Journal of Manpower 23(5), 443-457.

Lauer, Charlotte, 2003, Family background, cohort and education: A French-German comparison based on a multivariate ordered probit model of educational attainment, Labour Economics 10, 231-251.

Leslie, Derek and Stephen Drinkwater, 1999, Staying on in full-time education: reasons for higher participation rates among ethnic minority males and females, Economica 66, 63-77.

Maaz, Kai, 2006, Soziale Herkunft und Hochschulzugang, VS Verlag für Sozialwissenschaften, Wiesbaden.

Machin, Stephen and Anna Vignoles, 2004, Educational Inequality: The Widening Socio- Economic Gap, Fiscal Studies 25(2), 107-128.

Mayer, Adalbert, 2008, Education, Self-Selection, and Intergenerational Transmission of Abilities, Journal of Human Capital 2(1), 106-128.

Mayer, Karl Ulrich, Walter Müller, and Reinhard Pollak, 2007, Germany: Institutional Change and Inequalities of Access in Higher Education, in: Shavit, Yossi, Richard Arum, Adam Gamoran with Gila Menahem (eds.), Stratification in Higher Education. A Comparative Study, Stanford University Press, Stanford, 240-265.

OECD, 2007, Education at a Glance 2007, OECD, Paris.

Plomin, Robert, J.C. DeFries, G.E. McClearn, and P. McGuffin, 2001, Behavioral Genetics, fourth edition, New York: Freeman.

Plug, Erik and Wim Vijverberg, 2003, Schooling, Family Background, and Adoption: Is It Nature or Is It Nurture, Journal of Political Economy 111(3), 611-641.

Rice, Patricia G., 1987, The demand for post-secondary education in the UK and the effects of educational maintenance allowances, Economica 54, 465-475

SOEP Group, 2001, The German Socio-Economic Panel (SOEP) after more than 15 years - Overview. In: Elke Holst, Dean R. Lillard, and Thomas A. DiPrete (eds.): Proceedings of the 2000 Fourth International Conference of German Socio-Economic Panel Study Users (SOEP2000), Vierteljahrshefte zur Wirtschaftsforschung 70(1), 7-14.

StBA (Federal Statistical Office), 2006, Bildung im Zahlenspiegel 2006, Wiesbaden.

Steiner, Viktor and Katharina Wrohlich, 2008, Financial Student Aid and Enrollment into Higher Education: New Evidence from Germany, IZA Discussion Paper No. 3601, Bonn, Germany.

Tamm, Marcus, 2007, Does Money Buy Higher Schooling?, RWI Discussion Paper No. 55, Essen.

Wissenschaftsrat, 2008, Empfehlungen zur Qualitätsverbesserung von Lehre und Studium, Berlin 04.07.2008, Drs. 8639-08, (http://www.wissenschaftsrat.de/texte/8639-08.pdf of 22-07-2008). 
Table 1 Share of School Leavers Meeting Entry Requirements of Tertiary Education (in percent of the entire birth cohort at age 18-21)

\begin{tabular}{|c|c|c|c|c|c|c|}
\hline \multirow[t]{2}{*}{$\begin{array}{l}\text { Year of } \\
\text { School Exit }\end{array}$} & \multicolumn{2}{|c|}{$\begin{array}{c}\text { Access to } \\
\text { Any Tertiary Education }\end{array}$} & \multicolumn{4}{|c|}{$\begin{array}{l}\text { Access to } \\
\text { University }\end{array}$} \\
\hline & $\begin{array}{c}\text { Male } \\
\text { (1) }\end{array}$ & $\begin{array}{c}\text { Female } \\
\text { (2) }\end{array}$ & $\begin{array}{l}\text { Male } \\
\text { (3) }\end{array}$ & $\begin{array}{c}\text { Male-West } \\
\text { (4) }\end{array}$ & $\begin{array}{c}\text { Female } \\
\text { (5) }\end{array}$ & $\begin{array}{c}\text { Female-West } \\
(6)\end{array}$ \\
\hline 1980 & 23.6 & 20.8 & 17.3 & 17.3 & 16.5 & 16.5 \\
\hline 1985 & 28.4 & 27.3 & 21.2 & 21.2 & 21.9 & 21.9 \\
\hline 1990 & 33.0 & 29.8 & 22.6 & 22.6 & 23.2 & 23.2 \\
\hline 1995 & 34.7 & 38.1 & 25.2 & 24.8 & 30.5 & 27.6 \\
\hline 2000 & 33.8 & 40.9 & 24.2 & 24.7 & 31.2 & 29.9 \\
\hline 2005 & 39.4 & 45.6 & 24.9 & 25.2 & 32.8 & 32.3 \\
\hline
\end{tabular}

Notes: (a) Starting 1995 the overall figures represent united Germany. (b) Natives and foreigners are jointly depicted. (c) Columns 1 and 2 provide the cohort share of those meeting requirements for any tertiary education, including e.g. only to polytechnical universities. Columns 3-6 provide the cohort share of those leaving school with Abitur, and who have access to university study.

Source: Federal Statistical Office, 2007, FS 11 Reihe 4.3.1 (1980-2005), pp.108-116.

Table 2 Cohort Share of Entrants to Institutions of Tertiary Education

\begin{tabular}{lccc}
\hline Year of Entry & All & Male & Female \\
\hline 1980 & 20.4 & 23.9 & 16.7 \\
1985 & 19.9 & 23.3 & 16.2 \\
1990 & 27.3 & 31.8 & 22.6 \\
1995 & 26.8 & 26.6 & 27.0 \\
2000 & 33.5 & 33.4 & 33.6 \\
2005 & 37.0 & 37.1 & 36.9 \\
\hline
\end{tabular}

Notes: (a) The overall figures represent united Germany starting 1995. (b) The entries are calculated as share of each birth cohort in the year of entry to tertiary education. (c) Natives and foreigners are jointly represented. (d) The figures combine the university entry in the summer and the subsequent winter term. (e) The figures combine entrance to university with that to other institutions of tertiary education, e.g. polytechnical universities.

Source: Federal Statistical Office, 2007, FS 11 Reihe 4.3.1 (1980 - 2005), p.124. 
Table 3 Cohort Share of Graduates with Tertiary Education Degrees

\begin{tabular}{lccc}
\hline Year of Degree & All & Male & Female \\
\hline 1985 & 14.2 & 17.4 & 10.8 \\
1992 & 12.6 & - & - \\
1995 & 14.7 & - & - \\
1998 & 16.4 & 17.7 & 15.0 \\
2000 & 16.9 & 17.5 & 16.2 \\
2005 & 21.1 & 20.5 & 21.6 \\
\hline
\end{tabular}

Notes: (a) The overall figures represent united Germany starting 1995. (b) The entries are calculated as share of each birth cohort in the year of exiting tertiary education. (c) Natives and foreigners are jointly represented. (d) The figures combine degrees from all institutions of tertiary education.

Source: for 2000 and 2005: Federal Statistical Office, 2007, FS 11 Reihe 4.3 .1 (1980 - 2005), p.130, for 1998: Statistical Office, 2004, FS 11 Reihe 4.3 .1 (1980 - 2002), p.36, for 1992 and 1995: KMK 2005, p. 36*, for 1985: Köhler 1990, p.121

Table 4 Indicators of Tertiary education system

\begin{tabular}{ccccccc}
\hline Year & $\begin{array}{c}\text { Number of } \\
\text { Students } \\
\text { (winter term, } \\
\text { Univ. only) }\end{array}$ & $\begin{array}{c}\text { Students / } \\
\text { Professors } \\
\text { (Univ. only) }\end{array}$ & $\begin{array}{c}\text { Expenditures } \\
\text { on Tert. Educ. } \\
\text { (in Mio. Euro) }\end{array}$ & $\begin{array}{c}\text { Non- } \\
\text { Investment } \\
\text { Expenditures } \\
\text { / Student } \\
\text { (in Euro) } \\
\text { (4) }\end{array}$ & $\begin{array}{c}\text { Exp. as } \\
\text { share of } \\
\text { GDP }\end{array}$ & $\begin{array}{c}\text { Exp. per } \\
\text { inhabitant } \\
\text { (in Euro) }\end{array}$ \\
\hline 1975 & $\mathbf{( 1 )}$ & $\mathbf{( 2 )}$ & $\mathbf{( 3 )}$ & $\mathbf{( 5 )}$ & $\mathbf{( 6 )}$ \\
\hline 1980 & $\mathbf{6}$ & 391,289 & - & - & 1.1 & 91 \\
1985 & $1,035,669$ & 41.2 & - & - & 1.0 & 116 \\
1990 & $1,208,018$ & 58.2 & - & - & 0.9 & 140 \\
1995 & $1,409,345$ & 56.2 & - & - & 0.9 & 167 \\
2000 & $1,341,149$ & 55.9 & 24,996 & 7520 & 0.9 & 199 \\
2005 & $1,418,377$ & 60.4 & 30,509 & 8140 & 0.9 & 210 \\
\hline
\end{tabular}

Source: 1: Wissenschaftsrat, 2008, p. 106; 2: Wissenschaftsrat, 2008, p. 107;

3: Federal Statistical Office, 2007, FS 11 Reihe 4.5, p. 17.

4: Federal Statistical Office, 2007, FS 11 Reihe 4.3.2 2005, p. 37.

5,6: Federal Statistical Office, 2006, Bildung im Zahlenspiegel 2006, p. 121,169. 
Table 5 Delay in Transition to Tertiary Education for those Meeting Entry Requirements (Abitur 1984-2001)

\begin{tabular}{|c|c|c|c|c|c|c|c|c|}
\hline & \multirow{2}{*}{$\begin{array}{c}\text { Number of } \\
\text { Observations } \\
1984-2001\end{array}$} & \multicolumn{7}{|c|}{$\begin{array}{l}\text { Number and Share of High School Graduates } \\
\text { starting Tertiary Education }\end{array}$} \\
\hline & & $\begin{array}{l}\text { same } \\
\text { year }\end{array}$ & $\begin{array}{l}\text { after } 1 \\
\text { year }\end{array}$ & $\begin{array}{l}\text { after } 2 \\
\text { years }\end{array}$ & $\begin{array}{l}\text { after } 3 \\
\text { years }\end{array}$ & $\begin{array}{c}\text { after } 4 \\
\text { years }\end{array}$ & $\begin{array}{c}\text { after } 5 \\
\text { years }\end{array}$ & censored \\
\hline Female & $\begin{array}{c}521 \\
100 \%\end{array}$ & $\begin{array}{c}216 \\
41.5 \%\end{array}$ & $\begin{array}{c}55 \\
10.6 \%\end{array}$ & $\begin{array}{c}33 \\
6.3 \%\end{array}$ & $\begin{array}{c}18 \\
3.5 \%\end{array}$ & $\begin{array}{c}4 \\
0.8 \%\end{array}$ & $\begin{array}{c}1 \\
0.2 \%\end{array}$ & $\begin{array}{c}194 \\
37.2 \%\end{array}$ \\
\hline Male & $\begin{array}{c}480 \\
100 \%\end{array}$ & $\begin{array}{c}86 \\
17.9 \%\end{array}$ & $\begin{array}{c}166 \\
34.6 \%\end{array}$ & $\begin{array}{c}48 \\
10.0 \%\end{array}$ & $\begin{array}{c}20 \\
4.2 \%\end{array}$ & $\begin{array}{c}14 \\
2.9 \%\end{array}$ & $\begin{array}{c}5 \\
1.0 \%\end{array}$ & $\begin{array}{l}141 \\
29.4 \%\end{array}$ \\
\hline
\end{tabular}

Source: German Socioeconomic Panel (1984-2006), own calculations.

Table 6 Probability of Transition to Tertiary Education Parental Education conditional on Abitur 1984-2001

\begin{tabular}{|c|c|c|c|c|}
\hline & $\begin{array}{c}\text { Missing / } \\
\text { Other } \\
\text { (1) } \\
\end{array}$ & $\begin{array}{c}\text { None / Basic } \\
\text { School } \\
(2) \\
\end{array}$ & $\begin{array}{c}\text { Middle } \\
\text { School } \\
(3) \\
\end{array}$ & $\begin{array}{c}\text { Gymnasium or } \\
\text { Tertiary Degree } \\
\text { (4) }\end{array}$ \\
\hline \multicolumn{5}{|c|}{ Observed average propensity to enter university: } \\
\hline & $54 \%$ & $60 \%$ & $61 \%$ & $74 \%$ \\
\hline \multicolumn{5}{|c|}{ Predicted propensity to enter university given the income of parents in highest education group: } \\
\hline & $59 \%$ & $63 \%$ & $64 \%$ & $74 \%$ \\
\hline \multicolumn{5}{|l|}{ Difference: } \\
\hline & $4.2 \%$ & $2.8 \%$ & $2.5 \%$ & $-0.2 \%$ \\
\hline
\end{tabular}

Note: Predicted propensities are based on probit regressions performed separately by parental education group and controlling only for a constant and the percentile of household net equivalent income in the relevant annual income distribution.

Source: German Socioeconomic Panel (1984-2006), own calculations. 
Table 7 Descriptive Statistics - Full Panel Sample

\begin{tabular}{|c|c|c|c|c|}
\hline & \multicolumn{2}{|c|}{ Sample Abitur } & \multicolumn{2}{|c|}{ Sample Study } \\
\hline & Mean & Std. Dev. & Mean & Std. Dev. \\
\hline \multicolumn{5}{|l|}{ Dependent Variable } \\
\hline Abitur (0/1) & 0.080 & 0.271 & -- & -- \\
\hline Study (0/1) & -- & -- & 0.257 & 0.437 \\
\hline \multicolumn{5}{|l|}{ Independent Variables } \\
\hline Highest Parental Educ. Missing (0/1) & 0.102 & 0.302 & 0.055 & 0.228 \\
\hline Highest Parental Educ. Low (0/1) & 0.459 & 0.498 & 0.205 & 0.404 \\
\hline Highest Parental Educ. Medium (0/1) & 0.282 & 0.450 & 0.363 & 0.481 \\
\hline Highest Parental Educ. High (0/1) & 0.157 & 0.364 & 0.377 & 0.485 \\
\hline Age $17 / 18(0 / 1)$ & 0.320 & 0.466 & -- & -- \\
\hline Age $19 / 20(0 / 1)$ & 0.293 & 0.455 & -- & -- \\
\hline Age $21-25(0 / 1)$ & 0.387 & 0.487 & -- & -- \\
\hline Age at Abitur $17 / 18(0 / 1)$ & -- & -- & 0.066 & 0.248 \\
\hline Age at Abitur 19/20 (0/1) & -- & -- & 0.807 & 0.395 \\
\hline Age at Abitur 21-25 (0/1) & -- & -- & 0.127 & 0.333 \\
\hline \multicolumn{5}{|l|}{ Rank of household equivalent income at age 19: } \\
\hline First quartile (0/1) & 0.235 & 0.424 & 0.153 & 0.360 \\
\hline Second quartile (0/1) & 0.217 & 0.413 & 0.196 & 0.397 \\
\hline Third quartile (0/1) & 0.218 & 0.413 & 0.260 & 0.438 \\
\hline Fourth quartile (0/1) & 0.223 & 0.416 & 0.330 & 0.470 \\
\hline Income information missing (0/1) & 0.107 & 0.309 & 0.062 & 0.241 \\
\hline Male (0/1) & 0.511 & 0.500 & 0.491 & 0.500 \\
\hline Immigrant (0/1) & 0.187 & 0.390 & 0.061 & 0.239 \\
\hline Immigrant Information Missing (0/1) & 0.030 & 0.169 & 0.015 & 0.123 \\
\hline Year of Abitur (0/1) & -- & -- & 0.399 & 0.490 \\
\hline Year 1 after Abitur (0/1) & -- & -- & 0.249 & 0.433 \\
\hline Year 2 after Abitur (0/1) & -- & -- & 0.142 & 0.349 \\
\hline Year 3 after Abitur (0/1) & -- & -- & 0.094 & 0.292 \\
\hline Year 4 after Abitur (0/1) & -- & -- & 0.067 & 0.250 \\
\hline Year 5 after Abitur (0/1) & -- & -- & 0.049 & 0.216 \\
\hline \multicolumn{5}{|l|}{ State of Residence at time of Abitur: } \\
\hline City state $(0 / 1)$ & 0.053 & 0.225 & 0.073 & 0.261 \\
\hline Schleswig-Holstein/Lower Saxony (0/1) & 0.114 & 0.318 & 0.123 & 0.328 \\
\hline Rhineland-Palatinate/Hesse (0/1) & 0.126 & 0.332 & 0.097 & 0.296 \\
\hline Baden-Württemberg (0/1) & 0.158 & 0.365 & 0.133 & 0.339 \\
\hline Bavaria (0/1) & 0.137 & 0.344 & 0.080 & 0.271 \\
\hline Mecklenburg-Western Pomerania/Brandenburg (0/1) & 0.061 & 0.240 & 0.076 & 0.266 \\
\hline Saxony-Anhalt/Thuringia (0/1) & 0.076 & 0.266 & 0.112 & 0.315 \\
\hline Saxony (0/1) & 0.057 & 0.232 & 0.074 & 0.262 \\
\hline \multicolumn{5}{|l|}{ State share of pupils attending Gymnasium when starting } \\
\hline Gymnasium & 0.226 & 0.028 & -- & -- \\
\hline State with strict Gymnasium admission rules (0/1) & 0.437 & 0.496 & & \\
\hline Age of father when child was born & 29.372 & 5.951 & -- & -- \\
\hline Age father missing $(0 / 1)$ & 0.042 & 0.201 & -- & -- \\
\hline Age of mother when child was born & 26.276 & 5.514 & -- & -- \\
\hline Age mother missing (0/1) & 0.022 & 0.148 & -- & -- \\
\hline Number of observations & \multicolumn{2}{|c|}{36,739} & \multicolumn{2}{|c|}{2,936} \\
\hline
\end{tabular}

Note: Calendar year fixed effects as well as year of Abitur indicators not presented to save space. Northrhine-Westfalia is the reference group for the states of residence. All person-year observations in the "sample study" refer to individuals who obtained the Abitur degree.

Source: German Socioeconomic Panel (1984-2006), own calculations. 
Table 8 Estimation Results: Probit Marginal Effects of "Transition to Tertiary Education" with and without Sample Selection Correction in 3 Specifications

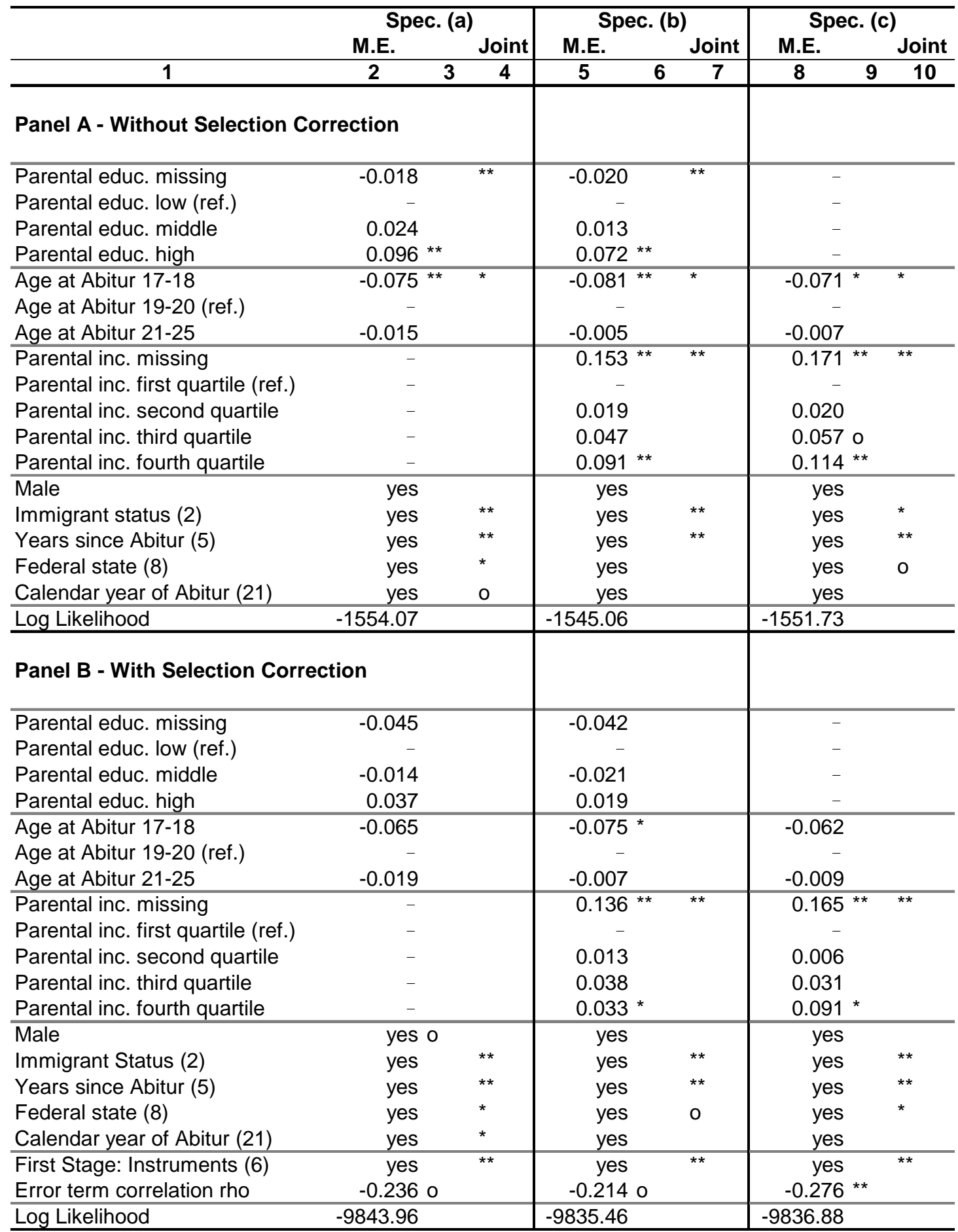

Note: The results in Panel A are based on 2,936 observations, those in Panel B on 36,739 observations, of which only 2,936 are used in the second stage regression. **, * and o indicate statistical significance at the 1,5 and 10 percent level. The figures in parentheses in column 1 indicate the number of coefficients estimated for the respective covariate vectors. Columns 2, 5 and 8 contain the marginal effects, columns 3, 6 and 9 indicate their individual statistical significance of the marginal effects and columns 4, 7 and 10 describe the joint statistical significance of the considered groups of covariates.

Source: German Socioeconomic Panel (1984-2006), own calculations. 
Table 9 Estimation Results: Probit Marginal Effects of "Transition to Tertiary Education" with and without Sample Selection Correction Separately for three Periods in West Germany

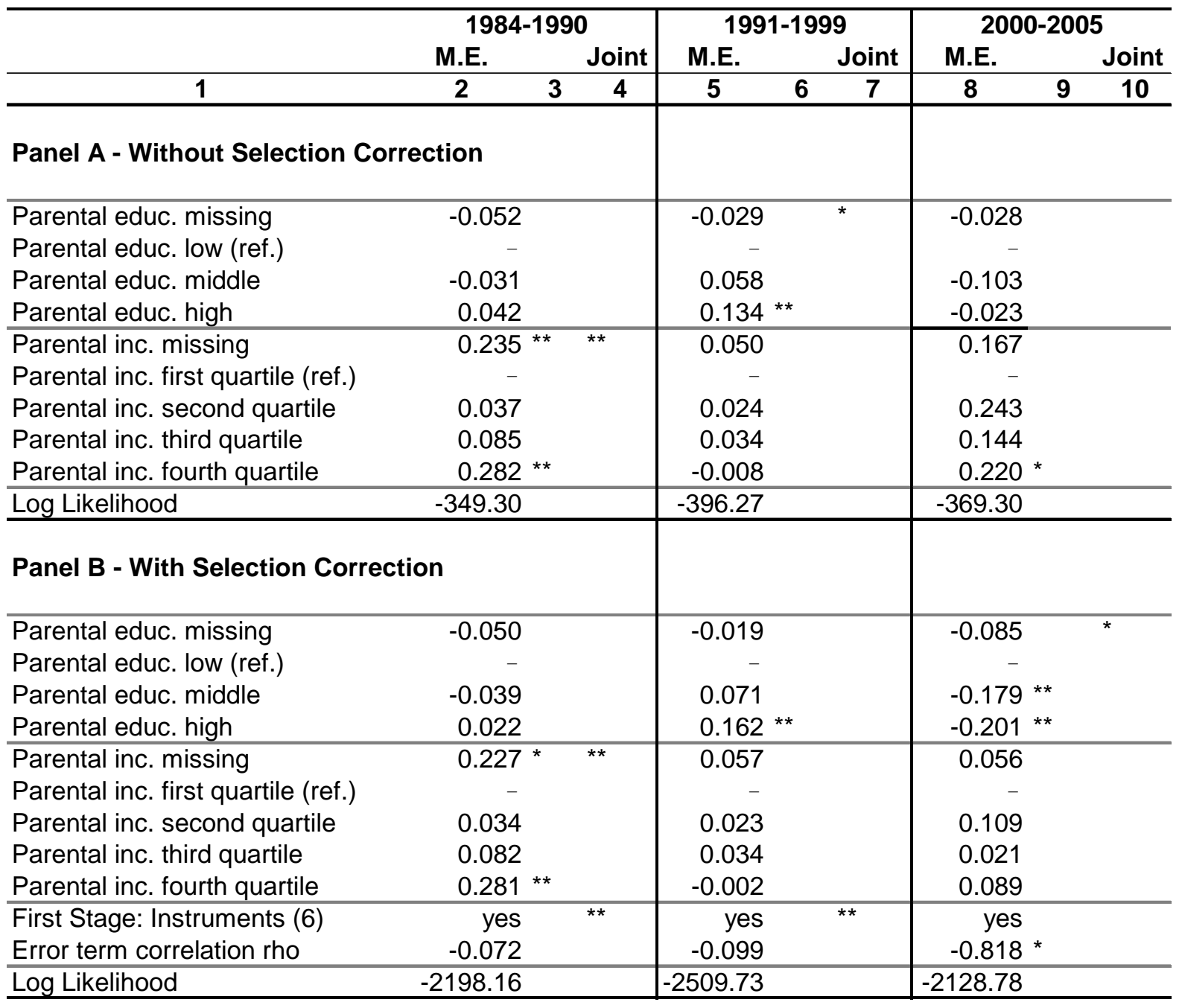

Note: See notes below Table 8. The empirical specifications are as in Table 8. Panel A is estimated on 707, 781, and 618 West German observations for the respective time periods. The estimations in Panel B use 9125, 10861, and 9137 observations for the three periods, respectively.

Source: German Socioeconomic Panel (1984-2006), own calculations. 
Table 10 Estimation Results: Probit Marginal Effects of "Transition to Tertiary Education" with and without Sample Selection Correction Separately for Men and Women in West Germany

\begin{tabular}{|c|c|c|c|c|}
\hline \multirow[b]{3}{*}{1} & \multicolumn{2}{|c|}{ Women } & \multicolumn{2}{|l|}{ Men } \\
\hline & M.E. & Joint & M.E. & Joint \\
\hline & 2 & 4 & 5 & 7 \\
\hline \multicolumn{5}{|c|}{ Panel A - Without Selection Correction } \\
\hline Parental educ. missing & -0.0990 & * & 0.139 & \\
\hline Parental educ. low (ref.) & - & & - & \\
\hline Parental educ. middle & 0.030 & & -0.021 & \\
\hline Parental educ. high & 0.084 * & & 0.050 & \\
\hline Parental inc. missing & 0.167 * & 0 & $0.225 * \star$ & * \\
\hline Parental inc. first quartile (ref.) & - & & - & \\
\hline Parental inc. second quartile & 0.087 & & 0.083 & \\
\hline Parental inc. third quartile & 0.091 & & $0.151 *$ & \\
\hline Parental inc. fourth quartile & $0.142 * \star$ & & $0.175 * \star$ & \\
\hline Log Likelihood & -507.80 & & -563.81 & \\
\hline \multicolumn{5}{|c|}{ Panel B - With Selection Correction } \\
\hline Parental educ. missing & $0.217 * \star$ & * & 0.155 & \\
\hline Parental educ. low (ref.) & - & & - & \\
\hline Parental educ. middle & -0.091 & & 0.005 & \\
\hline Parental educ. high & -0.120 & & 0.068 & \\
\hline Parental inc. missing & 0.091 & & $0.182 * \star$ & 0 \\
\hline Parental inc. first quartile (ref.) & - & & - & \\
\hline Parental inc. second quartile & 0.076 & & 0.050 & \\
\hline Parental inc. third quartile & 0.063 & & 0.090 & \\
\hline Parental inc. fourth quartile & 0.109 & & 0.126 o & \\
\hline First Stage: Instruments (6) & yes & ** & yes & ** \\
\hline Error term correlation rho & $-0.677 *$ & & 0.030 & \\
\hline Log Likelihood & -3403.23 & & -3634.41 & \\
\hline
\end{tabular}

Note: See notes below Table 8. The empirical specifications are as in Table 8. Panel A is estimated on 1,084 and 1,028 male and female West German observations. The estimations in Panel B use 14,875 and 14,248 observations for males and females, respectively.

Source: German Socioeconomic Panel (1984-2006), own calculations. 
Table 11 Estimation Results: Probit Marginal Effects of "Transition to Tertiary Education" with and without Sample Selection Correction Separately for East and West Germany

\begin{tabular}{|c|c|c|c|c|}
\hline \multirow{3}{*}{$\begin{array}{r} \\
1 \\
\end{array}$} & \multicolumn{2}{|c|}{ West 1991-2005 } & \multicolumn{2}{|c|}{ East 1991-2005 } \\
\hline & M.E. & Joint & M.E. & Joint \\
\hline & 2 & 4 & 5 & 7 \\
\hline \multicolumn{3}{|c|}{ Panel A - Without Selection Correction } & & \\
\hline Parental educ. missing & 0.003 & * & 0.019 & \\
\hline Parental educ. low (ref.) & - & & - & \\
\hline Parental educ. middle & 0.019 & & 0.028 & \\
\hline Parental educ. high & 0.090 & & 0.113 & \\
\hline Parental inc. missing & 0.080 & & 0.271 * & * \\
\hline Parental inc. first quartile (ref.) & - & & - & \\
\hline Parental inc. second quartile & 0.075 & & -0.055 & \\
\hline Parental inc. third quartile & 0.060 & & -0.027 & \\
\hline Parental inc. fourth quartile & 0.067 & & 0.022 & \\
\hline Log Likelihood & -774.88 & & -389.09 & \\
\hline \multicolumn{3}{|c|}{ Panel B - With Selection Correction } & & \\
\hline Parental educ. missing & -0.076 & & -0.071 & \\
\hline Parental educ. low (ref.) & - & & - & \\
\hline Parental educ. middle & $-0.158 *$ & & -0.069 & \\
\hline Parental educ. high & -0.1610 & & -0.072 & \\
\hline Parental inc. missing & 0.104 & & 0.301 * & ** \\
\hline Parental inc. first quartile (ref.) & - & & - & \\
\hline Parental inc. second quartile & 0.204 & & -0.129 & \\
\hline Parental inc. third quartile & 0.083 & & -0.140 o & \\
\hline Parental inc. fourth quartile & 0.170 & & -0.064 & \\
\hline First Stage: Instruments (6) & yes & ** & yes & * \\
\hline Error term correlation rho & -0.4690 & & $-0.670 * *$ & \\
\hline Log Likelihood & -2285.43 & & -2587.36 & \\
\hline
\end{tabular}

Note: See notes below Table 8. The empirical specifications are as in Table 8. Panel A is estimated on 1405 and 824 West and East German observations for the period between 1991 and 2005. The estimations in Panel B use 27,935 and 7616 observations for West and East Germany, respectively.

Source: German Socioeconomic Panel (1984-2006), own calculations. 
Figure 1 Population Share with Academic Entry Qualification (Abitur) and Completed Academic Degree (Univ. or Polytechnical Univ.) by Sex and Birth Cohort Group

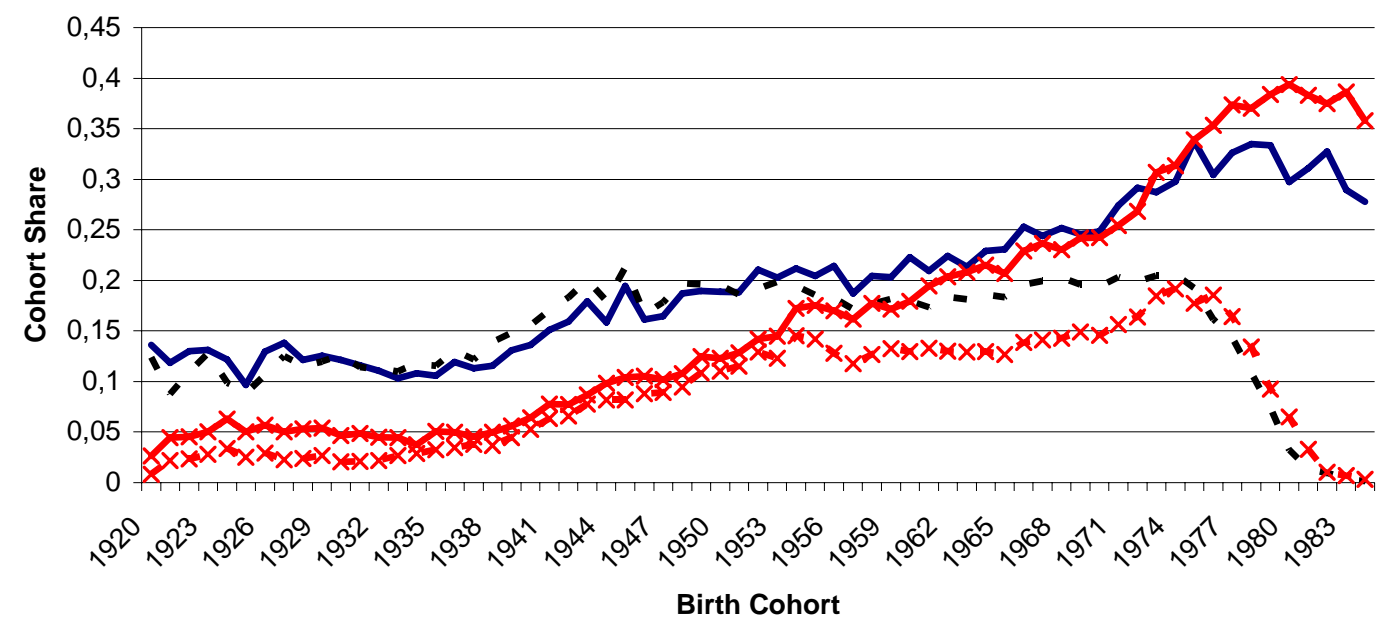

Abitur Males = - - Studies Males $\longleftarrow$ Abitur Females $=\ltimes$ - Studies Females

Note: $\quad$ Only considering individuals who indicate to be born in Germany.

Source: $\quad$ Mikrozensus of 2005, weighted data. 
Figure 2 Entry into Tertiary Education by Year of Attaining University Entrance Requirement

(a) Males

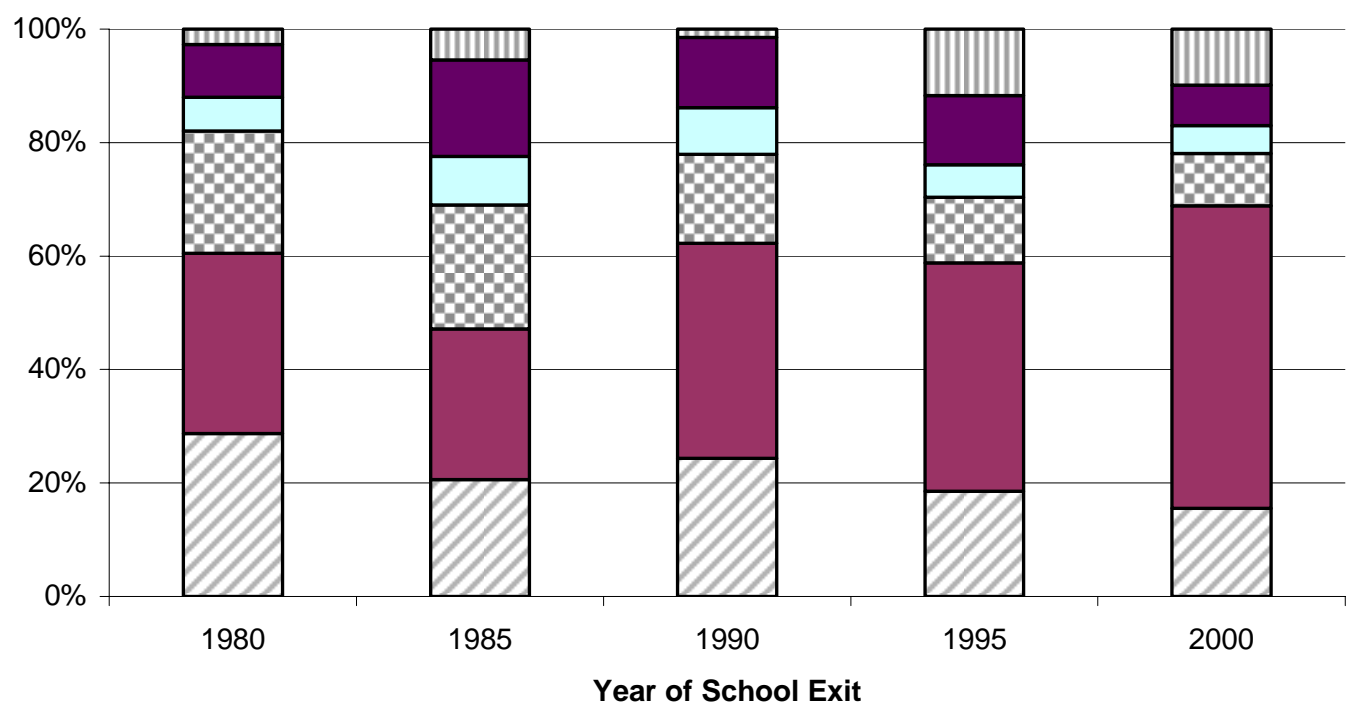

$\square$ same year $\square 1$ yr later $\square 2$ yrs later $\square 3$ yrs later $\square 4+$ yrs later $\square$ never

(b) Females

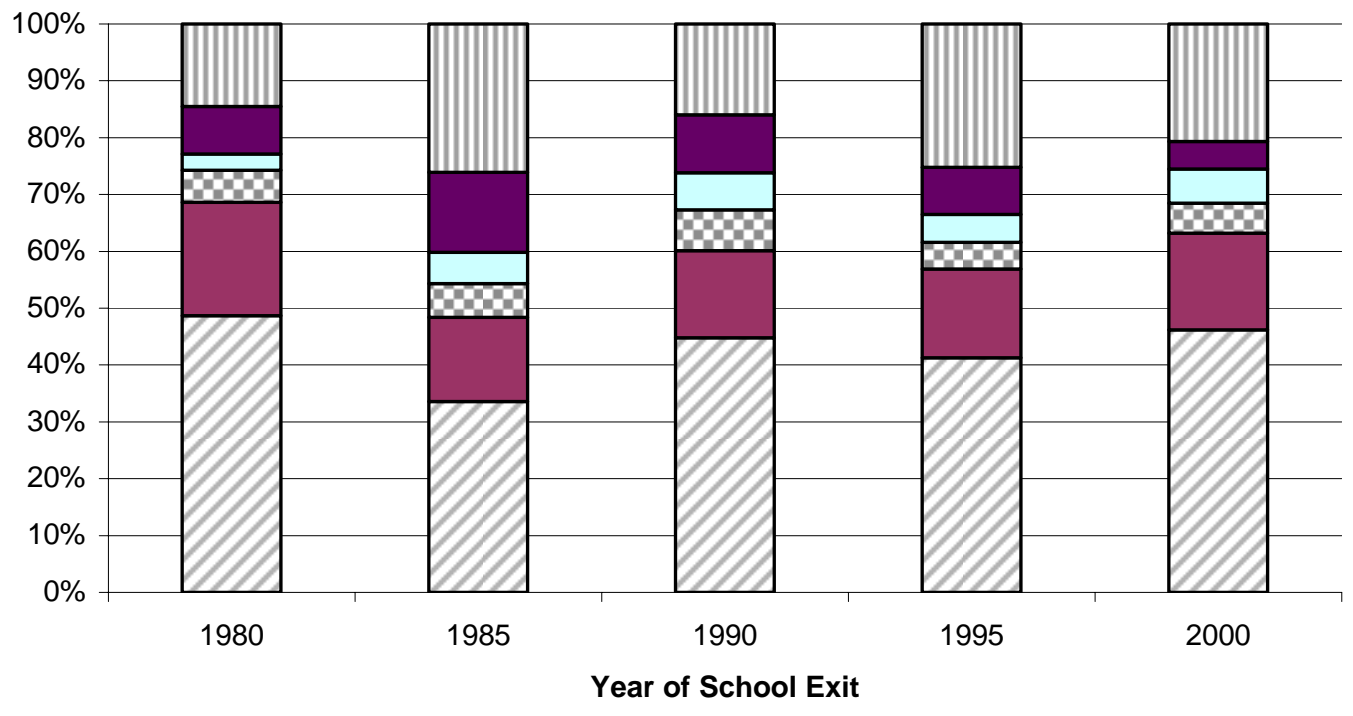

$\square$ same year $\square 1$ yr later $\square 2$ yrs later $\square 3$ yrs later $\square$ 4+ yrs later $\square$ never

Note: (a) Only individuals meeting general university entry requirements and their entry to universities are considered (i.e. entry to polytechnicals is not described). (b) The data for 1995 and 2000 cover united Germany. (c) The data represent natives and foreigners.

Source: Federal Statistical Office, 2007, Fachserie 11 - Reihe 4.3 .1 (1980 - 2005), pp.170-171. 
Figure 3 Annual Number of Entrants to Tertiary Education

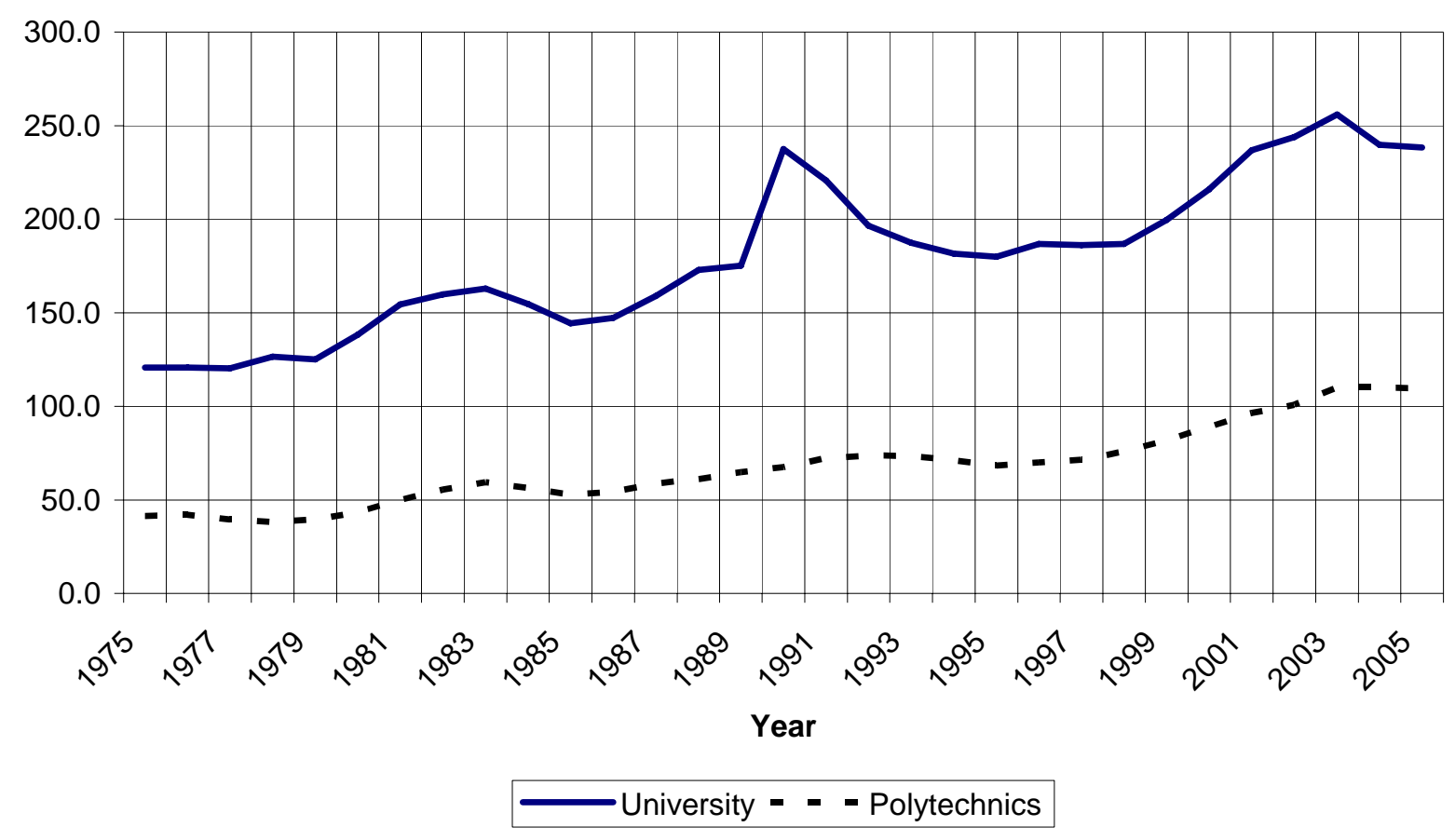

Source: Wissenschaftsrat, 2008, p.106 
Figure 4 Observed High School Degrees by Graduation Year and Sex

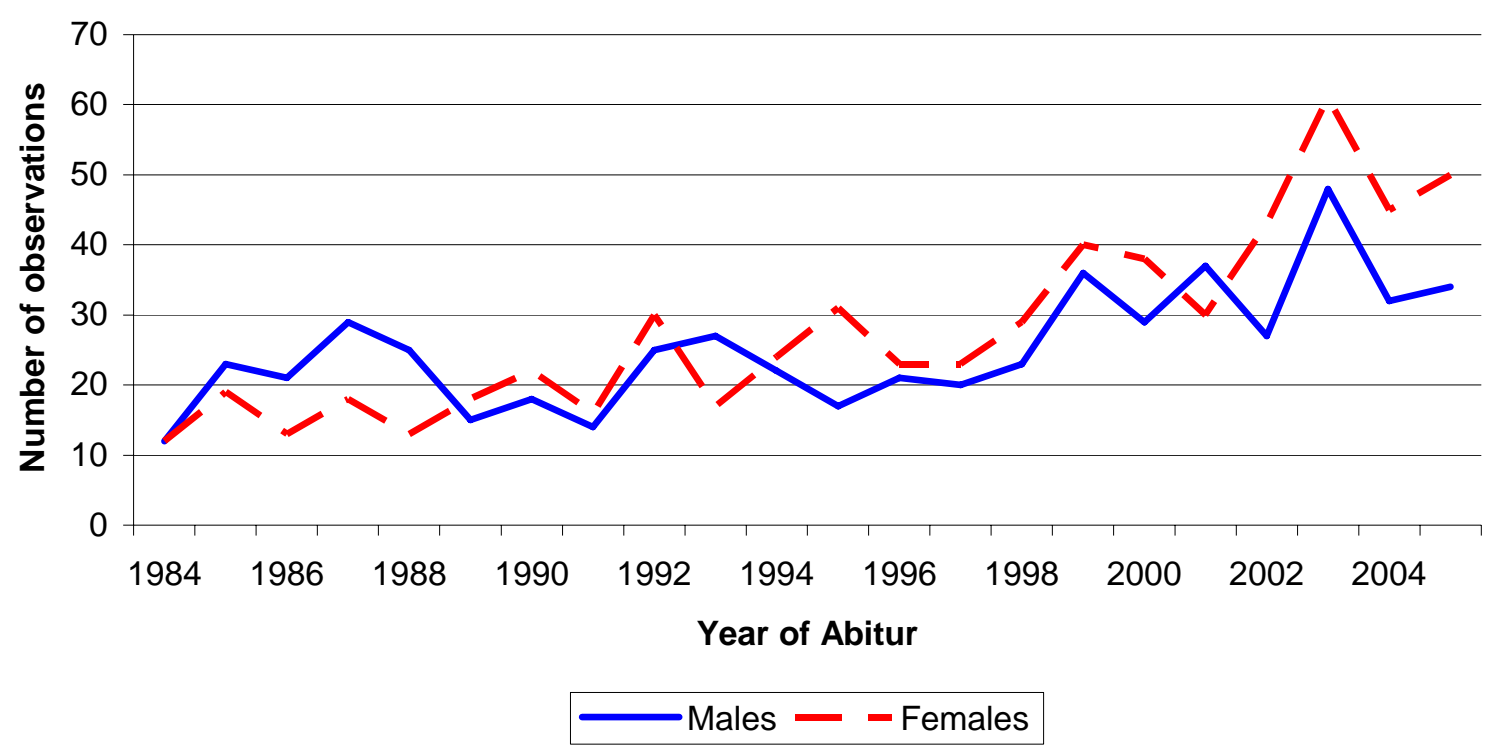

Note: The data is unweighted and does not account for shifts in the raw SOEP sample size over time. Source: German Socioeconomic Panel (1984-2006), own calculations.

Figure $5 \quad$ Age at Abitur by Sex

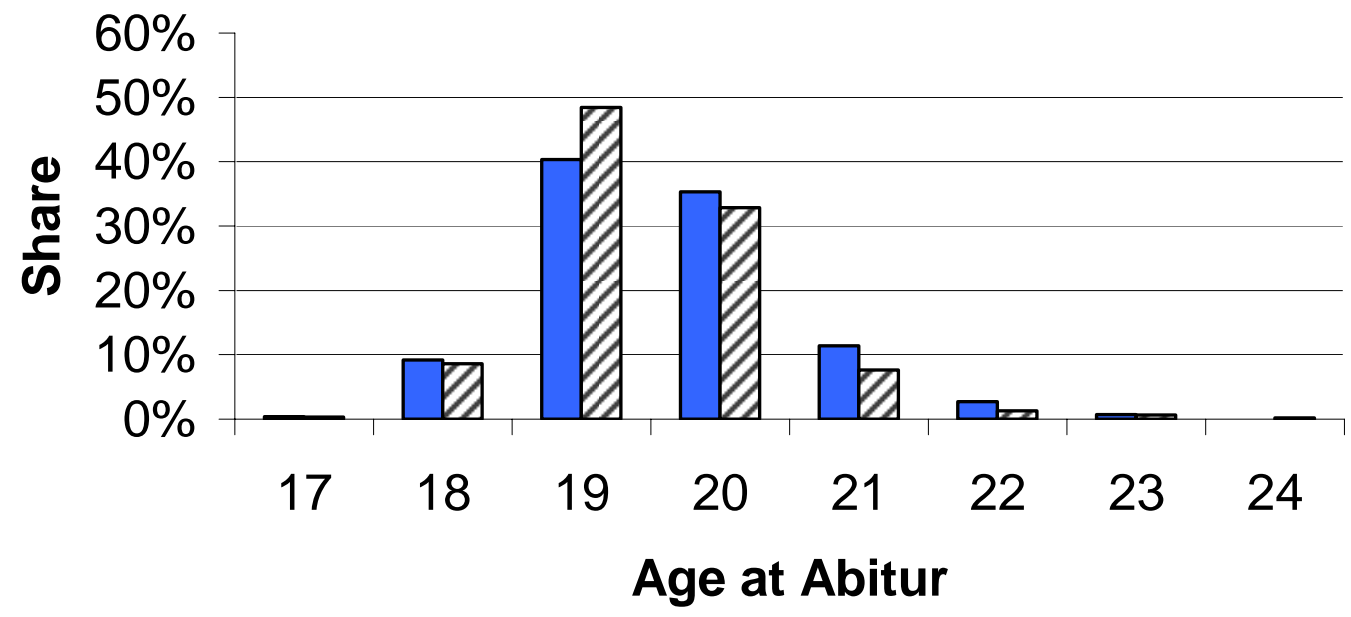

\section{Males $\square$ Females}

Source: German Socioeconomic Panel (1984-2006), own calculations. 
Figure 6 Share of Gymnasium Graduates Commencing Tertiary Education by Year of Abitur

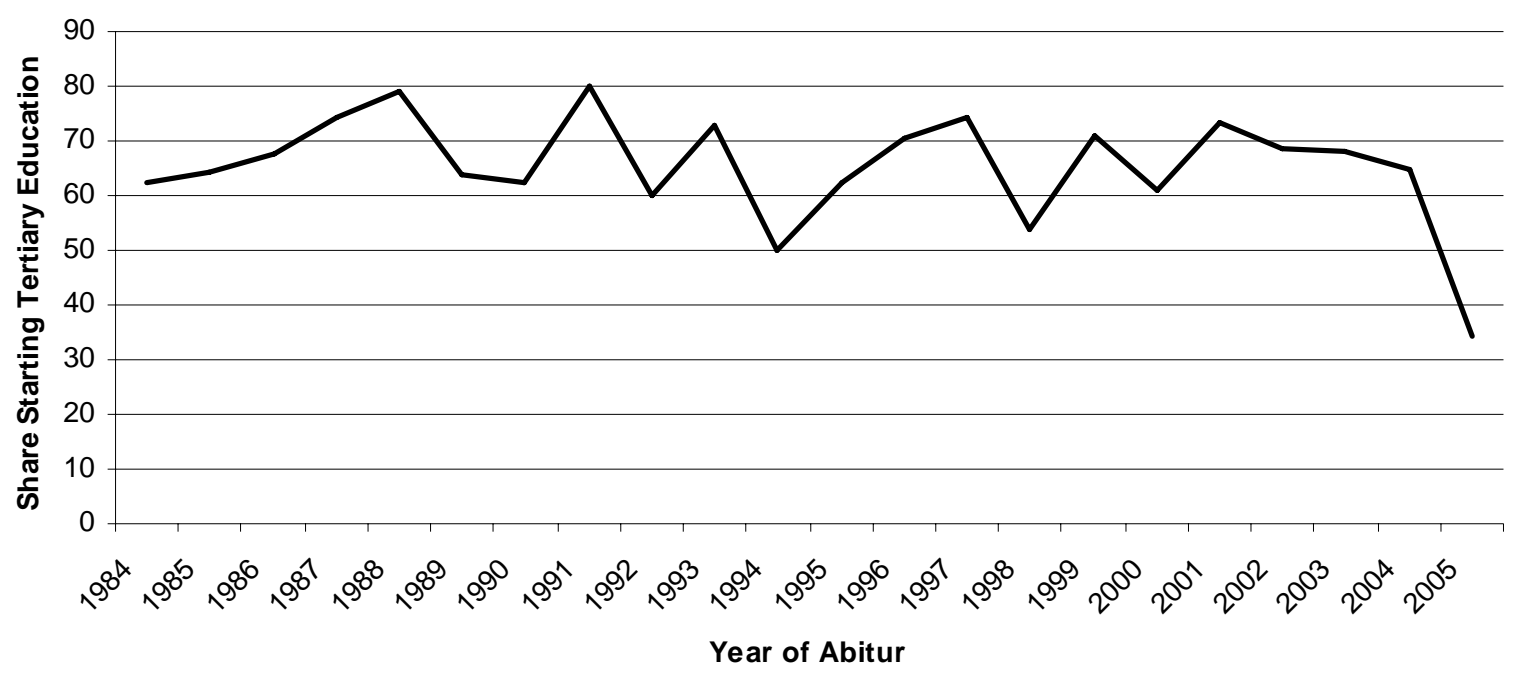

Source: German Socioeconomic Panel (1984-2006), own calculations. 
Figure 7 Probability of Educational Outcomes by Parental Income and Education

(a) Probability of a Attaining the Abitur Degree

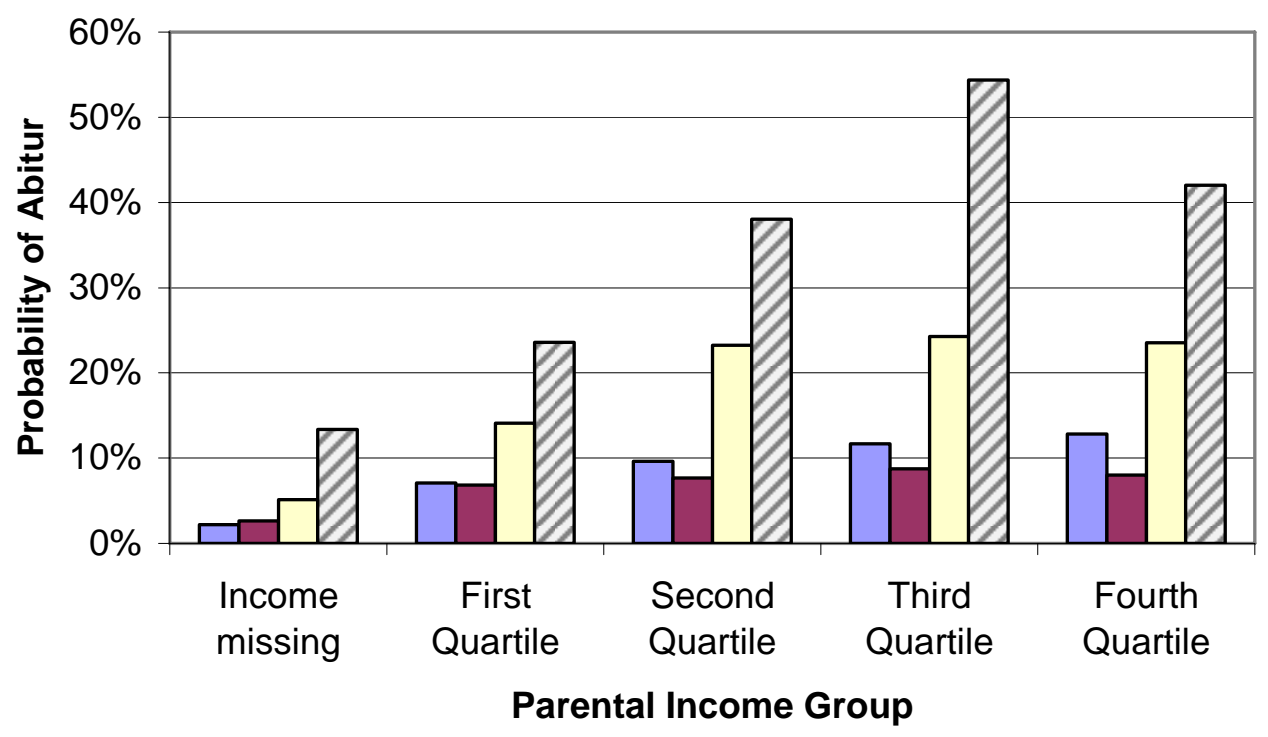

$\square$ Parent educ. missing $\square$ Parent educ. low

$\square$ Parent educ. middle $\square$ Parent educ. high

(b) Probability of Transition to Tertiary Education, Conditional on Attaining the Abitur Degree

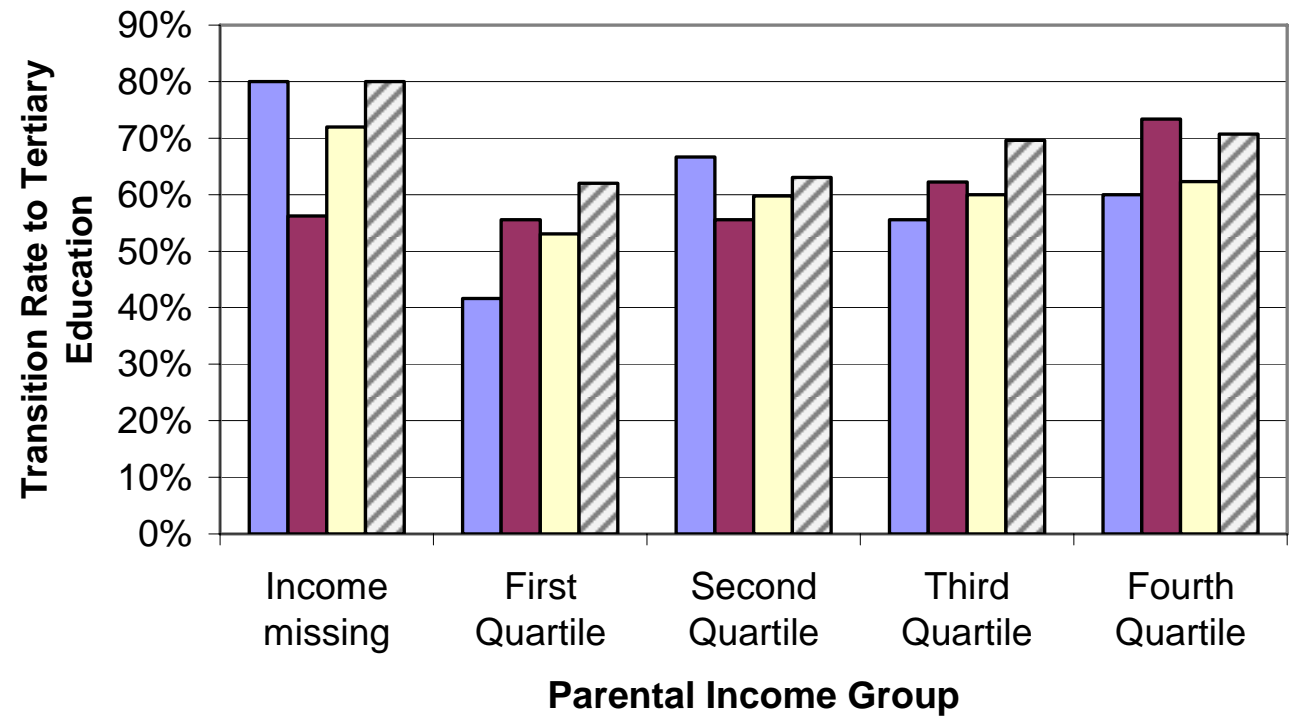

$\square$ Parent educ. missing $\square$ Parent educ. low

$\square$ Parent educ. middle $\square$ Parent educ. high

Note: The income percentiles reflect the rank of household equivalent income when the youth was age 19. The data consider all Abitur events and transitions to tertiary education observed between 1984 and 2006.

Source: German Socioeconomic Panel (1984-2006), own calculations. 


\section{Appendix}

Table A1: $\quad$ First Stage Regression for Table 8 Specification (b)

\begin{tabular}{|c|c|}
\hline & $\begin{array}{l}\text { Spec. (b) } \\
\text { ME }\end{array}$ \\
\hline 1 & 2 \\
\hline Parental educ. missing & $0.030 *$ \\
\hline Parental educ. low (reference) & - \\
\hline Parental educ. middle & 0.060 * \\
\hline Parental educ. high & $0.159 *$ \\
\hline Age 17-18 & $-0.091 *$ \\
\hline Age 19-20 (reference) & - \\
\hline Age 21-25 & -0.003 \\
\hline Parental inc. missing & $0.030 *$ \\
\hline Parental inc. first quartile (reference) & - \\
\hline Parental inc. second quartile & $0.017 *$ \\
\hline Parental inc. third quartile & $0.027 *$ \\
\hline Parental inc. fourth quartile & 0.023 * \\
\hline Male & yes ** \\
\hline Immigrant status (2) & yes * \\
\hline Federal state (7) & yes * \\
\hline Calendar year of Abitur (21) & yes * \\
\hline Father age at birth & 0.001 ** \\
\hline Father age at birth missing & $-0.026 *$ \\
\hline Mother age at birth & 0.001 * \\
\hline Mother age at birth missing & 0.012 \\
\hline State year cohort share at Gymnasium & 0.256 * \\
\hline State restrictive Gymnasium access & 0.007 * \\
\hline
\end{tabular}

Note: $* *$, , and ${ }^{0}$ indicate statistical significance at the 1,5 , and 10 percent level.

Source: German Socioeconomic Panel (1984-2006), own calculations. 
Table A2: $\quad$ Reestimation of Table 8 with Income Residuals

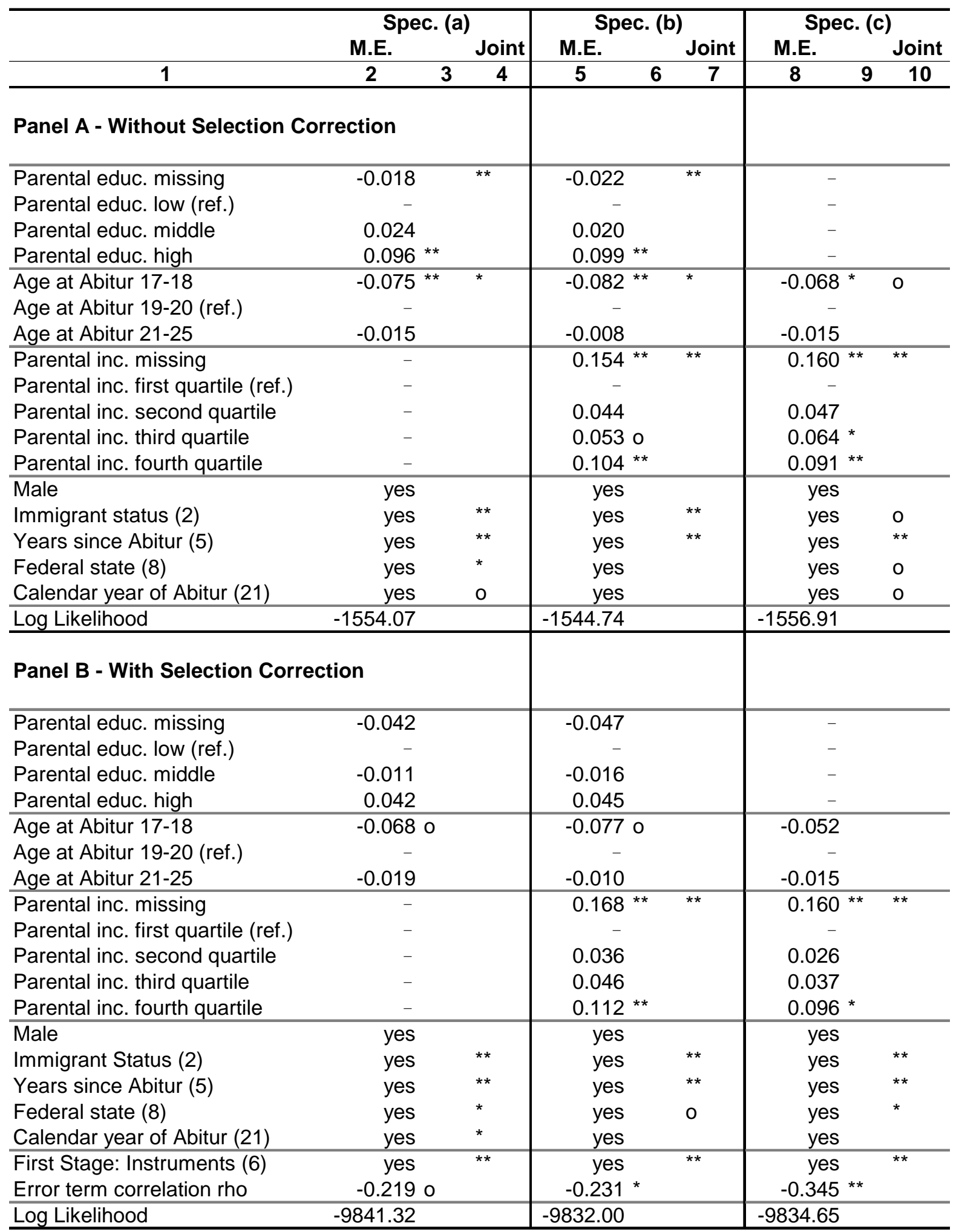

Note: $\quad * *, *$, and ${ }^{\circ}$ indicate statistical significance at the 1,5 , and 10 percent level. The empirical model is identical to that used in Table 8.

Source: German Socioeconomic Panel (1984-2006), own calculations. 
Table A3: $\quad$ Results of Subsample with Grades: With and Without Grade control

\begin{tabular}{|c|c|c|c|c|c|c|}
\hline \multirow[b]{3}{*}{1} & \multicolumn{2}{|c|}{ Spec. (a) } & \multicolumn{2}{|c|}{ Spec. (b) } & \multicolumn{2}{|c|}{ Spec. (c) } \\
\hline & $\begin{array}{l}\text { W/o Grades } \\
\text { M.E. }\end{array}$ & $\begin{array}{l}\text { With Grades } \\
\text { M.E. }\end{array}$ & $\begin{array}{l}\text { W/o Grades } \\
\text { M.E. }\end{array}$ & \multirow{2}{*}{$\begin{array}{l}\text { With Grades } \\
\text { M.E. } \\
\mathbf{8} \\
\end{array}$} & $\begin{array}{c}\text { W/o Grades } \\
\text { M.E. }\end{array}$ & $\begin{array}{l}\text { With Grades } \\
\text { M.E. }\end{array}$ \\
\hline & 2 & 5 & 7 & & 10 & 12 \\
\hline \multicolumn{7}{|c|}{ Panel A - Without Selection Correction } \\
\hline P. educ. missing & 0.018 & -0.009 & -0.001 & -0.027 & - & - \\
\hline P. educ. low (ref.) & - & - & - & - & - & - \\
\hline P. educ. middle & -0.028 & -0.043 & -0.046 & -0.059 & - & - \\
\hline P. educ. high & 0.042 & 0.046 & 0.005 & 0.009 & - & - \\
\hline P. inc. missing & - & - & 0.014 & 0.019 & 0.030 & 0.041 \\
\hline P. inc. first quartile (ref.) & - & - & - & - & - & - \\
\hline P. inc. second quartile & - & - & -0.017 & -0.013 & -0.015 & -0.013 \\
\hline P. inc. third quartile & - & - & 0.014 & 0.028 & 0.022 & 0.039 \\
\hline P. inc. fourth quartile & - & - & 0.082 & 0.095 & 0.097 & 0.114 \\
\hline Grades (4) & - & yes ** & - & yes ** & - & yes ** \\
\hline Log Likelihood & -544.42 & -537.61 & -541.88 & -534.74 & -542.91 & -536.54 \\
\hline \multicolumn{7}{|c|}{ Panel B - With Selection Correction } \\
\hline P. educ. missing & -0.037 & -0.065 & -0.063 & -0.089 & - & - \\
\hline P. educ. low (ref.) & - & - & - & - & - & - \\
\hline P. educ. middle & -0.103 & -0.121 & -0.1250 & -0.1410 & - & - \\
\hline P. educ. high & -0.113 & -0.110 & $-0.154 *$ & -0.1470 & - & - \\
\hline P. inc. missing & - & - & 0.007 & 0.010 & 0.016 & 0.025 \\
\hline P. inc. first quartile (ref.) & - & - & - & - & - & - \\
\hline P. inc. second quartile & - & - & -0.046 & -0.044 & -0.037 & -0.035 \\
\hline P. inc. third quartile & - & - & -0.062 & -0.050 & -0.026 & -0.013 \\
\hline P. inc. fourth quartile & - & - & 0.017 & 0.031 & 0.041 & 0.055 \\
\hline Grades (4) & - & yes ** & - & yes * & - & yes ** \\
\hline First Stage: Instruments (6) & yes * & yes * & yes * & yes * & yes ** & yes ** \\
\hline Error term correlation rho & $-0.537 * \star$ & -0.534 ** & $-0.565 * \star$ & $-0.540 * *$ & $-0.342 *$ & $-0.364 * *$ \\
\hline Log Likelihood & -3210.45 & -3203.74 & -3208.37 & -3201.67 & -3210.38 & -3203.68 \\
\hline
\end{tabular}

Note: In the odd numbered columns **, $*$, and ${ }^{\circ}$ indicate joint statistical significance at the 1,5 , and 10 percent level. All models were specified as the base case in Table 8. As indicators of pupil ability all models control for grades in mathematics, German, a foreign language and an indicator if grade information is missing. The Probit estimations in Panel A use 918 observations, the estimations with selection controls in Panel B are based on 1957 observations.

Source: $\quad$ German Socioeconomic Panel (1984-2006), own calculations. 